The Canadian Mineralogist

Vol. 38, pp. 627-639 (2000)

\title{
NIOBOKUPLETSKITE, A NEW ASTROPHYLLITE-GROUP MINERAL FROM MONT SAINT-HILAIRE, QUEBEC, CANADA: DESCRIPTION AND CRYSTAL STRUCTURE
}

\author{
PAULA C. PIILONEN ${ }^{\S}$ AND ANDRÉ E. LALONDE \\ Ottawa-Carleton Geoscience Centre, Department of Earth Sciences, University of Ottawa, Ottawa, Ontario K1N 6N5, Canada
}

ANDREW M. McDONALD

Department of Earth Sciences, Laurentian University, Sudbury, Ontario P3E 2C6, Canada

ROBERT A. GAULT

Research Division, Canadian Museum of Nature, P.O. Box 3443, Station D, Ottawa, Ontario K1P 6P4, Canada

\begin{abstract}
Niobokupletskite is a new member of the astrophyllite group found in nepheline syenite pegmatites at Mont Saint-Hilaire, Quebec, in association with aegirine, albite, analcime, calcio-ancylite-(Ce), calcite, catapleiite, epididymite, fluorite, genthelvite, microcline, natrolite, pyrochlore, rhodochrosite and wurtzite. It is transparent, with a vitreous luster, brittle with a perfect $\{001\}$ cleavage, and has an uneven to splintery fracture. Niobokupletskite is biaxial positive, $\alpha 1.718(1), \beta 1.733(1), \gamma_{\text {calc }} 1.750(1)$, $2 V_{\text {meas }}=87(2)^{\circ}$. It is triclinic, $P \overline{1}, a$ 5.4303(9), $b$ 11.924(2), $c$ 11.747(2) A, $\alpha$ 112.927(3), $\beta$ 94.750(3), $\gamma 103.175(3)^{\circ}$, $V$ 669.5(3) $\AA^{3}$. The average result of three electron-microprobe analyses is: $\mathrm{Na}_{2} \mathrm{O} 2.62, \mathrm{~K}_{2} \mathrm{O} 5.97, \mathrm{Rb}_{2} \mathrm{O} 0.82, \mathrm{Cs}_{2} \mathrm{O} 0.12$, $\mathrm{MgO} 0.15, \mathrm{MnO} 26.37, \mathrm{FeO} 2.64, \mathrm{ZnO} 4.08, \mathrm{Al}_{2} \mathrm{O}_{3} 1.14, \mathrm{TiO}_{2} 1.34, \mathrm{ZrO}_{2} 3.43, \mathrm{Nb}_{2} \mathrm{O}_{5} 12.13, \mathrm{Ta}_{2} \mathrm{O}_{5} 0.63, \mathrm{SiO}_{2} 31.85, \mathrm{~F} 0.14$, $\mathrm{H}_{2} \mathrm{O}$ (calc.) 2.48, total 95.85 wt.\%, corresponding to $\left(\mathrm{K}_{1.84} \mathrm{Rb}_{0.13} \mathrm{Cs}_{0.01}\right)_{\Sigma 1.98} \mathrm{Na}_{0.95}\left(\mathrm{Mn}_{5.40} \mathrm{Zn}_{0.73} \mathrm{Fe}_{0.53} \mathrm{Na}_{0.28} \mathrm{Mg}_{0.05}\right)_{\Sigma 6.99}$ $\left(\mathrm{Nb}_{1.33} \mathrm{Zr}_{0.40} \mathrm{Ti}_{0.24} \mathrm{Ta}_{0.04}\right)_{\Sigma 2.01}\left(\mathrm{Si}_{7.71} \mathrm{Al}_{0.32}\right)_{\Sigma 8.03} \mathrm{O}_{26}(\mathrm{OH})_{4.00}\left(\mathrm{O}_{0.89} \mathrm{~F}_{0.11}\right)_{\Sigma 1.00}$ on the basis of 31 anions, or, ideally, $\mathrm{K}_{2} \mathrm{Na}(\mathrm{Mn}, \mathrm{Zn}, \mathrm{Fe})_{7}\left(\mathrm{Nb}, \mathrm{Zr}, \mathrm{Ti}_{2} \mathrm{Si}_{8} \mathrm{O}_{26}(\mathrm{OH})_{4}(\mathrm{O}, \mathrm{F})\right.$. Niobokupletskite is a heterophyllosilicate with a $\mathrm{HOH}$-structure consisting of a sheet of close-packed octahedra $(O$-sheet) sandwiched between two heterogeneous sheets ( $H$-sheets) with a Si:Nb ratio of 4:1. It forms a solid-solution series with kupletskite via the coupled substitution $\mathrm{Ti}^{4+}+\mathrm{F}^{-}$or $\mathrm{OH}^{-} \Leftrightarrow \mathrm{Nb}^{5+}+\mathrm{O}^{2-}$. Niobokupletskite is a postmagmatic phase and possibly the result of late-stage remobilization of $\mathrm{Nb}$ via late oxidized aqueous fluids.
\end{abstract}

Keywords: niobokupletskite, astrophyllite-group mineral, new mineral species, crystal structure, heterophyllosilicate, solidsolution series, kupletskite, Mont Saint-Hilaire, Quebec.

\section{SOMMAIRE}

La niobokupletskite est une nouvelle espèce minérale, membre du groupe de l'astrophyllite, que l'on retrouve dans les pegmatites syénitiques à néphéline du Mont Saint-Hilaire, Québec, en association avec aegyrine, analcime, calcite, catapléite, épididymite, fluorite, genthelvite, microcline, natrolite, pyrochlore, rhodochrosite et wurtzite. C'est un minéral transparent, avec éclat vitreux, cassant, avec un clivage $\{001\}$ parfait et une fracture irrégulière à fibreuse. La niobokupletskite est biaxe positive, avec $\alpha 1.718(1), \beta 1.733(1), \gamma_{\text {calc }} 1.750(1), 2 V_{\text {observé }}=87(2)^{\circ}$. Le minéral est triclinique, groupe spatial $P \overline{1}$, avec paramètres

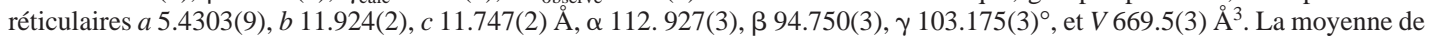
trois déterminations de la composition par microsonde électronique a donné: $\mathrm{Na}_{2} \mathrm{O} 2.62, \mathrm{~K}_{2} \mathrm{O} 5.97, \mathrm{Rb}_{2} \mathrm{O} 0.82, \mathrm{Cs}_{2} \mathrm{O} 0.12, \mathrm{MgO}$ 0.15, $\mathrm{MnO} 26.37, \mathrm{FeO} 2.64, \mathrm{ZnO} 4.08, \mathrm{Al}_{2} \mathrm{O}_{3} 1.14, \mathrm{TiO}_{2} 1.34, \mathrm{ZrO}_{2} 3.43, \mathrm{Nb}_{2} \mathrm{O}_{5} 12.13, \mathrm{Ta}_{2} \mathrm{O}_{5} 0.63, \mathrm{SiO}_{2} 31.85, \mathrm{~F} 0.14, \mathrm{H} 2 \mathrm{O}$ (calc.) 2.48, somme $95.85 \%$ en poids, ce qui correspond à la formule structurale $\left(\mathrm{K}_{1.84} \mathrm{Rb}_{0.13} \mathrm{Cs}_{0.01}\right)_{\Sigma 1.98} \mathrm{Na}_{0.95}\left(\mathrm{Mn}_{5.40} \mathrm{Zn}_{0.73} \mathrm{Fe}_{0.53} \mathrm{Na}_{0.28}\right.$ $\left.\mathrm{Mg}_{0.05}\right)_{\Sigma 6.99}\left(\mathrm{Nb}_{1.33} \mathrm{Zr}_{0.40} \mathrm{Ti}_{0.24} \mathrm{Ta}_{0.04}\right)_{\Sigma 2.01}\left(\mathrm{Si}_{7.71} \mathrm{Al}_{0.32}\right)_{\Sigma 8.03} \mathrm{O}_{26}(\mathrm{OH})_{4.00}\left(\mathrm{O}_{0.89} \mathrm{~F}_{0.11}\right)_{\Sigma 1.00}$ sur une base de 31 anions, ou, de façon idéale, $\mathrm{K}_{2} \mathrm{Na}(\mathrm{Mn}, \mathrm{Zn}, \mathrm{Fe})_{7}\left(\mathrm{Nb}, \mathrm{Zr}, \mathrm{Ti}_{2} \mathrm{Si}_{8} \mathrm{O}_{26}(\mathrm{OH})_{4}(\mathrm{O}, \mathrm{F})\right.$. La niobokupletskite est un hétérophyllosilicate ayant une struture $H O H$ composée d'une couche d'octaèdres avec entassement maximal se retrouvant entre deux couches hétérogènes (couches $H$ ) ayant un rapport $\mathrm{Si}: \mathrm{Nb}$ de $4: 1$. Elle fait partie d'une solution solide avec la kupletskite selon la substitution $\mathrm{Ti}^{4+}+\mathrm{F}^{-}$ou $\mathrm{OH}^{-} \Leftrightarrow \mathrm{Nb}^{5+}$ $+\mathrm{O}^{2-}$. La niobokupletskite est d'origine postmagmatique et provient possiblement d'une remobilisation tardive du $\mathrm{Nb}$ par le biais d'une phase aqueuse tardive oxydée.

Mots-clés: niobokupletskite, minéral du groupe de l'astrophyllite, Mont Saint-Hilaire, Québec, nouvelle espèce minérale, structure cristalline, hétérophyllosilicate, solution solide, kupletskite.

§E-mail address: ppiilon@science.uottawa.ca 


\section{INTRODUCTION}

Niobokupletskite, ideally $\mathrm{K}_{2} \mathrm{Na}(\mathrm{Mn}, \mathrm{Zn}, \mathrm{Fe})_{7}$ $(\mathrm{Nb}, \mathrm{Zr}, \mathrm{Ti})_{2} \mathrm{Si}_{8} \mathrm{O}_{26}(\mathrm{OH})_{4}(\mathrm{O}, \mathrm{F})$, is a new member of the astrophyllite group discovered in the nepheline syenite pegmatites in the Poudrette Quarry at Mont SaintHilaire, Québec. With the addition of niobokupletskite, the Nb-dominant analogue of kupletskite, eight species of astrophyllite-group minerals are now recognized (Table 1). Niobokupletskite is the third member of the astrophyllite group, along with astrophyllite and kupletskite, to be described from this locality (Horváth $\&$ Gault 1990). The name niobokupletskite comes from the fact that it is the $\mathrm{Nb}$-analogue of kupletskite (Semenov 1956). The mineral species and the name have been approved by the IMA Commission on New Minerals and New Mineral Names. Holotype material has been deposited at the Canadian Museum of Nature, Ottawa (catalogue no. CMNMC 82924). The purpose in this paper is to describe niobokupletskite, discuss its structure in relation to kupletskite, and to comment on its paragenesis. Extensive information concerning the structure and chemical variations of a large suite of astrophyllite-group minerals, including niobokupletskite, will be presented in future papers.

\section{OCCURRENCE AND DESCRIPTION}

Mont Saint-Hilaire (MSH), located $40 \mathrm{~km}$ east of Montreal, Quebec, is one of ten early Cretaceous alkaline intrusions collectively referred to as the Monteregian Hills (Adams 1903). The peralkaline East Hill Suite is host to a variety of petrological microenvironments (Piilonen et al. 1998), all of which contain astrophyllite-group minerals except for the so-called marble xenoliths. Niobokupletskite occurs in nepheline syenite pegmatites as a late-stage mineral.

TABLE 1. MEMBERS OF THE ASTROPHYLLITE GROUP

\begin{tabular}{|c|c|}
\hline Species & Formula \\
\hline${ }^{1}$ Niobokupletskite & $\mathrm{K}_{2} \mathrm{Na}(\mathrm{Mn}, \mathrm{Zn}, \mathrm{Fe})_{7}\left(\mathrm{Nb}, \mathrm{Zr}, \mathrm{Ti}_{2}\right)_{2} \mathrm{Si}_{8} \mathrm{O}_{26}(\mathrm{OH})_{4}(\mathrm{O}, \mathrm{F})$ \\
\hline${ }^{2}$ Kupletskite & $(\mathrm{K}, \mathrm{Na})_{3}\left(\mathrm{Mn}, \mathrm{Fe}^{2-}\right)_{7}(\mathrm{Ti}, \mathrm{Nb})_{2} \mathrm{Si}_{8} \mathrm{O}_{24}(\mathrm{O}, \mathrm{OH})_{7}$ \\
\hline${ }^{3}$ Cesium-kupletskite & $(\mathrm{Cs}, \mathrm{K}, \mathrm{Na})_{3}(\mathrm{Mn}, \mathrm{Fe}, \mathrm{Li})_{7}\left(\mathrm{Ti}_{7} \mathrm{Nb}_{2} \mathrm{Si}_{8} \mathrm{O}_{24}(\mathrm{O}, \mathrm{OH}, \mathrm{F})_{7}\right.$ \\
\hline${ }^{4}$ Astrophyllite & $(\mathrm{K}, \mathrm{Na})_{3}\left(\mathrm{Fe}^{28}, \mathrm{Mn}\right)_{7} \mathrm{Ti}_{2} \mathrm{Si}_{8} \mathrm{O}_{24}(\mathrm{O}, \mathrm{OH})_{7}$ \\
\hline${ }^{5}$ Magnesium astrophyllite & $\mathrm{K}_{2} \mathrm{NaNa}(\mathrm{Fe}, \mathrm{Mn})_{4} \mathrm{Mg}_{2} \mathrm{Ti}_{2} \mathrm{Si}_{8} \mathrm{O}_{24}(\mathrm{OH})_{4}(\mathrm{OH}, \mathrm{F})_{2}$ \\
\hline${ }^{6}$ Niobophyllite & $(\mathrm{K}, \mathrm{Na})_{3}\left(\mathrm{Fe}^{2-}, \mathrm{Mn}\right)_{6}(\mathrm{Nb}, \mathrm{Ti})_{2} \mathrm{Si}_{8} \mathrm{O}_{24}(\mathrm{O}, \mathrm{OH}, \mathrm{F})_{7}$ \\
\hline${ }^{7}$ Zircophyllite & $(\mathrm{K}, \mathrm{Na}, \mathrm{Ca})_{3}\left(\mathrm{Mn}, \mathrm{Fe}^{2+}\right)_{2}(\mathrm{Zr}, \mathrm{Nb})_{2} \mathrm{Si}_{8} \mathrm{O}_{27}(\mathrm{OH}, \mathrm{F})_{4}$ \\
\hline${ }^{8}$ Hydroastrophyllite & $\left(\mathrm{H}_{3} \mathrm{O}, \mathrm{K}, \mathrm{Ca}\right)_{3}\left(\mathrm{Fe}^{2 \dagger}, \mathrm{Mn}\right)_{5-6} \mathrm{Ti}_{2} \mathrm{Si}_{8}(\mathrm{O}, \mathrm{OH})_{31}$ \\
\hline
\end{tabular}

${ }^{1}$ this study, ${ }^{2}$ Semenov (1956), ${ }^{3}$ Efimov et al. (1971), ${ }^{4}$ Peng \& Ma (1963), ${ }^{5}$ Shi $e t$ al (1998), ${ }^{6}$ Nickel et al. (1965), ${ }^{7}$ Kapustin $1973,{ }^{8}$ Hubei Geological College (1974).
Three distinct types of niobokupletskite have been discovered, each with its own specific occurrence and associated mineral assemblage. Type-I niobokupletskite (holotype material) occurs as anhedral to subhedral, platy to tabular, light beige to yellow epitaxic overgrowths on primary, dark brown kupletskite associated with aegirine, albite, microcline and pyrochlore. The primary kupletskite is zoned; it possesses a relatively Ti-rich core and a $\mathrm{Nb}$-enriched rim; this zonation is indicated by an arrow in Figure 1B, with dark zones in this back-scattered electron (BSE) image corresponding to Ti-enrichment, and light zones indication of $\mathrm{Nb}$ enrichment. Type-II niobokupletskite occurs as a dense, fibrous, light yellow-brown overgrowth on coarse-
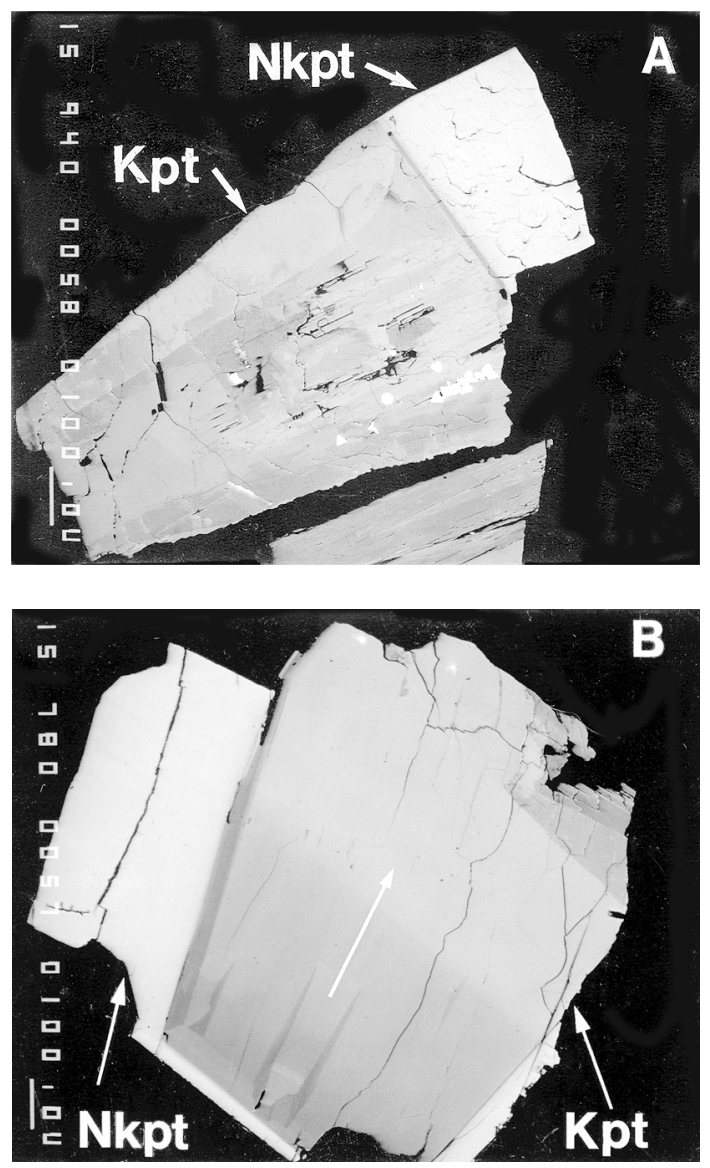

FIG. 1. Back-scattered electron images of type-I niobokupletskite. A. Nb-rich kupletskite (Kpt, dark grey) with irregular zonation and a sharp contact with niobokupletskite (Nkpt, light grey). Note the pyrochlore inclusions (white) along fractures in the kupletskite. B. Niobokupletskite (Nkpt) rimming kupletskite (Kpt). The zoning in the kupletskite is from $\mathrm{Nb}$-poor to $\mathrm{Nb}$-rich in the direction of the arrow (dark to medium grey). Scale bar: $100 \mu \mathrm{m}$. 
grained primary kupletskite associated with primary and secondary aegirine, albite, calcio-ancylite-(Ce), catapleiite, microcline, natrolite, pyrochlore and rhodochrosite. Type-III niobokupletskite occurs as an overgrowth on primary kupletskite as very fine-grained bronze to silvery brown acicular crystals in sheaf-like aggregates, originally described as "witch's broom astrophyllite" (Wight \& Chao 1986). Type-III niobokupletskite is associated with primary and secondary aegirine, albite, analcime, calcio-ancylite-(Ce), calcite, catapleiite, epididymite, fluorite, genthelvite, microcline, natrolite, pyrochlore, rhodochrosite, and wurtzite.

Niobokupletskite has a perfect $\{001\}$ cleavage, is vitreous, brittle, and has an uneven to splintery fracture. It does not fluoresce under either short- or long-wave ultraviolet light. It has a Mohs hardness of 3 to 4 . Niobokupletskite sinks in methylene iodide (density of $3.325 \mathrm{~g} / \mathrm{cm}^{3}$ ) and has a calculated density of $3.46 \mathrm{~g} / \mathrm{cm}^{3}$.

Niobokupletskite is biaxial positive, with indices of refraction $\alpha 1.718(1), \beta 1.733(1)$, and $\gamma_{\text {calc }} 1.750$ (for $\lambda=598 \mathrm{~nm}$ ); $2 V_{\text {meas }}=87(2)^{\circ}$ (Kamb's method). A measured value for $\gamma$ could not be obtained owing to the orientation of the selected grain on the spindle. The optical orientation is $Z=c$ with $X$ and $Y$ in the (001) plane. It is pleochroic with $X \approx Y$ light orange-yellow, and $Z$ red-brown. A Gladstone-Dale calculation gives a compatibility index of 0.005 , which is regarded as superior (Mandarino 1981).

\section{Chemical Composition}

Chemical analyses of type-I, -II and -III niobokupletskite were done on a JEOL 733 electron microprobe at the Canadian Museum of Nature using Tracor Northern 5500 and 5600 automation in wavelength-dispersion mode. The operating conditions were as follows: beam diameter $20 \mu \mathrm{m}$, operating voltage $15 \mathrm{kV}$, and a beam current of $20 \mathrm{nA}$. Data reduction was performed using a PAP routine in XMAQNT (C. Davidson, CSIRO). Overlap corrections for $\mathrm{Si}(K \alpha)-\operatorname{Sr}(L \alpha), \operatorname{Zr}(L \beta)-\mathrm{Nb}(L \alpha)$ and $\operatorname{Mn}(K \beta)-\mathrm{Nb}(L \alpha)$ were done. A total of 24 elements were sought, and the following standards were employed: Na-amphibole $(\mathrm{Na} K \alpha, \mathrm{Si} K \alpha)$, sanidine $(\mathrm{K} K \alpha, \mathrm{A} 1 K \alpha)$, diopside $(\mathrm{Ca} K \alpha, \mathrm{Mg} K \alpha)$, tephroite $(\mathrm{Mn} K \alpha)$, almandine $(\mathrm{Fe} K \alpha)$, rutile $(\mathrm{Ti} K \alpha)$, synthetic $\mathrm{MnNb}_{2} \mathrm{O}_{6}(\mathrm{Nb} L \alpha)$, vlasovite $(\mathrm{Zr} L \alpha)$, zincite $(\mathrm{Zn} L \alpha)$, phlogopite $(\mathrm{F} K \alpha)$, pollucite $(\mathrm{Cs} L \alpha)$, celestite $(\operatorname{Sr} L \alpha)$, sanbornite $(\mathrm{Ba} L \alpha)$, synthetic rubicline $(\mathrm{Rb} L \alpha)$, synthetic $\mathrm{NiTa}_{2} \mathrm{O}_{6}(\mathrm{Ta} M \alpha)$, and hafnon $(\mathrm{Hf} M \alpha)$. Count times for all elements were 25 seconds or $0.5 \%$ precision, whichever was obtained first, except for $\mathrm{Cs}$ and $\mathrm{Rb}$ (100 seconds), and Hf (50 seconds). Also sought but not detected were La, Ce, Yb, P, Th, Pb, Ni, V, U, W, Sc, S and Mo. Complete electron-microprobe data can be found in Table 2. Chemical formulae were calculated on the basis of 31 anions, as determined during crystal-structure analysis. The average of three compositions of type-I niobokupletskite gives the empirical formula $\left(\mathrm{K}_{1.84}\right.$

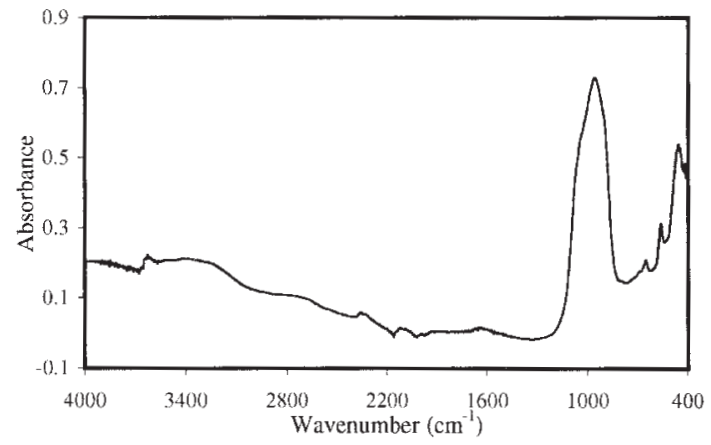

FIG. 2. Infrared transmittance spectrum of niobokupletskite.

$\left.\mathrm{Rb}_{0.13} \mathrm{Cs}_{0.01}\right)_{\Sigma 1.98} \mathrm{Na}_{0.95}\left(\mathrm{Mn}_{5.40} \mathrm{Zn}_{0.73} \mathrm{Fe}_{0.53} \mathrm{Na}_{0.28}\right.$ $\left.\mathrm{Mg}_{0.05}\right)_{\Sigma 6.99}\left(\mathrm{Nb}_{1.33} \mathrm{Zr}_{0.40} \mathrm{Ti}_{0.24} \mathrm{Ta}_{0.04}\right)_{\Sigma 2.01}\left(\mathrm{Si}_{7.71} \mathrm{Al}_{0.32}\right)$ $\Sigma_{28.03} \mathrm{O}_{26}(\mathrm{OH})_{4.00}\left(\mathrm{O}_{0.89} \mathrm{~F}_{0.11}\right)_{\Sigma 1.00}$, or, ideally, $\mathrm{K}_{2} \mathrm{Na}$ $(\mathrm{Mn}, \mathrm{Zn}, \mathrm{Fe})_{7}(\mathrm{Nb}, \mathrm{Zr}, \mathrm{Ti})_{2} \mathrm{Si}_{8} \mathrm{O}_{26}(\mathrm{OH})_{4}(\mathrm{O}, \mathrm{F})$. Chemically, type-II and type-III niobokupletskite differ from the type material only by being deficient in $\mathrm{Zn}(<0.04$ atoms per formula unit, apfu, Table 2).

\section{INFRARED ANALYSIS}

The infrared spectrum of niobokupletskite was obtained using a Bomem Michelson MB-100 Fourier transform infrared spectrometer equipped with a mercury cadmium telluride (MCT) detector. A single crystal of the type material was initially dried in an oven at $50^{\circ} \mathrm{C}$ for 30 minutes, mounted in a diamond-anvil microsample cell, and the spectrum collected over the range of 4000 to $400 \mathrm{~cm}^{-1}$. The absorbance spectrum (Fig. 2) shows broad peaks in the high-frequency range (4000 to $1000 \mathrm{~cm}^{-1}$ ) attributable to $\mathrm{O}-\mathrm{H}$ stretching $\left(3626 \mathrm{~cm}^{-1}\right.$ and associated shoulder centered at 3396 $\mathrm{cm}^{-1}$ ), and a weak peak at $1647 \mathrm{~cm}^{-1}$ attributable to $\mathrm{H}-\mathrm{O}-\mathrm{H}$ bending of absorbed or molecular $\mathrm{H}_{2} \mathrm{O}$ (Farmer 1974). The lack of recognizable $\mathrm{H}_{2} \mathrm{O}$ in the structure refinement suggests that this contribution is likely due to adsorbed water not driven off during the drying process. The middle- to lower-frequency end of the spectrum $\left(1000\right.$ to $\left.400 \mathrm{~cm}^{-1}\right)$ is characterized by symmetric $\mathrm{Si}-\mathrm{O}$ stretching (964 and $812 \mathrm{~cm}^{-1}$ ) and bending (696 and $654 \mathrm{~cm}^{-1}$ ). Low-frequency bands at 457, 418 and $405 \mathrm{~cm}^{-1}$ can be attributed to $\mathrm{Mn}-\mathrm{O}$ stretching (Farmer 1974).

\section{Mössbauer Spectroscopy}

The wide range of chemical compositions and the presence of structural vacancies preclude the possibility of using stoichiometry to calculate $\mathrm{Fe}^{2+} / \mathrm{Fe}^{3+}$ values in astrophyllite-group minerals. Mössbauer spectroscopy was therefore employed to determine the proportion and distribution of $\mathrm{Fe}^{2+}$ and $\mathrm{Fe}^{3+}$ in niobokupletskite 
TABLE 2. CHEMICAL COMPOSITION OF NIOBOKUPLETSKITE*, MONT SAINT-HILAIRE, QUEBEC

\begin{tabular}{|c|c|c|c|c|c|c|c|c|c|c|c|c|c|}
\hline \multirow[b]{2}{*}{ Oxide } & \multicolumn{4}{|c|}{ TYPE I } & \multirow{2}{*}{$\begin{array}{c}\text { TYPE } \\
\text { II }\end{array}$} & \multirow{2}{*}{$\begin{array}{c}\text { TYPE } \\
\text { III }\end{array}$} & \multicolumn{5}{|c|}{ TYPE I } & \multirow{2}{*}{$\begin{array}{l}\text { TYPE } \\
\text { II }\end{array}$} & \multirow{2}{*}{$\begin{array}{c}\text { TYPE } \\
\text { UII }\end{array}$} \\
\hline & 1 & 2 & 3 & Ave. & & & Oxide & 1 & 2 & 3 & Ave. & & \\
\hline $\mathrm{Na}_{2} \mathrm{O}$ wt. $\%$ & 2.69 & 2.49 & 2.67 & 2.62 & 2.37 & 2.66 & \multicolumn{7}{|c|}{ Formula based on 31 anions } \\
\hline $\mathrm{K}_{2} \mathrm{O}$ & 6.03 & 5.92 & 5.95 & 5.97 & 6.04 & 5.76 & & & & & & & \\
\hline $\mathrm{Rb}_{2} \mathrm{O}$ & 0.82 & 0.81 & 0.84 & 0.82 & 0.66 & 0.91 & K apfu & 1.85 & 1.83 & 1.84 & 1.84 & 1.83 & 1.75 \\
\hline $\mathrm{Cs}_{2} \mathrm{O}$ & 0.12 & 0.13 & 0.10 & 0.12 & 0.00 & 0.00 & $\mathrm{Rb}$ & 0,13 & 0.13 & 0.13 & 0.13 & 0.10 & 0.14 \\
\hline $\mathrm{CaO}$ & 0.00 & 0.00 & 0,00 & 0.00 & 0.10 & 0.03 & $\mathrm{Cs}$ & 0.01 & 0.01 & 0.01 & 0.01 & 0.00 & 0.00 \\
\hline $\mathrm{SrO}$ & 0.00 & 0.00 & 0.00 & 0.00 & 0.04 & 0.00 & $\mathrm{Sr}$ & 0.00 & 0.00 & 0.00 & 0.00 & 0.01 & 0.00 \\
\hline $\mathrm{MgO}$ & 0.13 & 0.15 & 0.18 & 0.15 & 0.18 & 0.43 & $\mathrm{Na}$ & 0.00 & 0.00 & 0.00 & 0.00 & 0.07 & 0.19 \\
\hline $\mathrm{MnO}$ & 26.11 & 26.40 & 26.61 & 26.37 & 26.60 & 30.13 & $\operatorname{Sum} A$ & 1.99 & 1.97 & 1.99 & 1.98 & 2.01 & 2.08 \\
\hline $\mathrm{FeO}$ & 2.63 & 2.73 & 2.55 & 264 & 7.44 & 3.71 & & & & & & & \\
\hline $\mathrm{ZnO}$ & 4.31 & 4.29 & 3.65 & 4.08 & 0.25 & 0.00 & & & & & & & \\
\hline $\mathrm{Al}_{2} \mathrm{O}_{3}$ & 1.21 & 1.02 & 1.20 & 1.14 & 1.18 & 1.69 & $\mathrm{Na}$ & 0.90 & 0.98 & 0.97 & 0.95 & 1.04 & 1.18 \\
\hline $\mathrm{TiO}_{2}$ & 112 & 1.26 & 1.65 & 1.34 & 1.63 & 1.67 & $\mathrm{Ca}$ & 0.00 & 0.00 & 0.00 & 0.00 & 0.03 & 0.01 \\
\hline $\mathrm{ZrO}_{2}$ & 3.23 & 4.23 & 2.84 & 3.43 & 4.80 & 3.56 & Sum $B$ & 0.90 & 0.98 & 0.97 & 0.95 & 1.00 & 1.00 \\
\hline $\mathrm{HFO}_{2}$ & 0.00 & 0.00 & 0.00 & 0.00 & 0.04 & 0.00 & & & & & & & \\
\hline $\mathrm{Nb}_{2} \mathrm{O}_{5}$ & 12.84 & 11.54 & 12.00 & 12.13 & 10.64 & 11,40 & $\mathrm{Na}$ & 0.35 & 0.20 & 0.29 & 0.28 & 0.05 & 0.05 \\
\hline $\mathrm{Ta}_{2} \mathrm{O}_{3}$ & 0.44 & 0.74 & 0.71 & 0.63 & 0.48 & 0.25 & $\mathrm{Mg}$ & 0.05 & 0.05 & 0.07 & 0.05 & 0.06 & 0.15 \\
\hline $\mathrm{SiO}_{2}$ & 31.93 & 31.80 & 31.82 & 31.85 & 32.06 & 31.86 & $\mathrm{Mn}$ & 5,31 & 5.43 & 5.48 & 5.40 & 5.36 & 6.06 \\
\hline F & 0.43 & 0.00 & 0.00 & 0.14 & 0.34 & 0.29 & $\mathrm{Fe}^{2+}$ & 0.53 & 0.55 & 0.52 & 0.53 & 1.48 & 0.74 \\
\hline \multirow[t]{2}{*}{$\mathrm{H}_{2} \mathrm{O}$} & 2.50 & 2.47 & 2.47 & 2.48 & 2.52 & 2.52 & $\mathrm{Zn}$ & 0.76 & 0.77 & 0.66 & 0.73 & 0.04 & 0.00 \\
\hline & & & & & & & $\operatorname{Sum} C$ & 7.00 & 7.00 & 7.00 & 7.00 & 7.00 & 7.00 \\
\hline \multirow[t]{2}{*}{$\mathrm{O}=\mathrm{F}$} & -0.18 & 0.00 & 0.00 & -0.06 & -0.14 & -0.12 & & & & & & & \\
\hline & & & & & & & $\mathrm{Ti}$ & 0.20 & 0.23 & 0.30 & 0.24 & 0.29 & 0.30 \\
\hline \multirow[t]{13}{*}{ Total } & 96.36 & 95.98 & 95.24 & 95.85 & 97.23 & 96.75 & $\mathrm{Zr}$ & 0.38 & 0.50 & 0.34 & 0.41 & 0.56 & 0.41 \\
\hline & & & & & & & $\mathrm{Hf}$ & 0.00 & 0.00 & 0.00 & 0.00 & 0.00 & 0.00 \\
\hline & & & & & & & $\mathrm{Nb}$ & 1.39 & 1.27 & 1.32 & 1.33 & 1.14 & 1.23 \\
\hline & & & & & & & $\mathrm{Ta}$ & 0.03 & 0.05 & 0.05 & 0.04 & 0.03 & 0.02 \\
\hline & & & & & & & $\operatorname{Sum} D$ & 2.00 & 2.05 & 2.00 & 2.02 & 2.03 & 1.95 \\
\hline & & & & & & & $\mathrm{Si}$ & 7.67 & 7.72 & 7.73 & 7.71 & 7.62 & 7.57 \\
\hline & & & & & & & $\mathrm{Al}$ & 0.34 & 0.29 & 0.34 & 0.33 & 0.33 & 0.47 \\
\hline & & & & & & & Sum $T$ & 8.01 & 8.01 & 8.08 & 8.03 & 7.96 & 8.04 \\
\hline & & & & & & & 0 & 26.67 & 27.00 & 27.00 & 2689 & 26.74 & 26.78 \\
\hline & & & & & & & $\mathrm{OH}$ & 4.00 & 4.00 & 4.00 & 4.00 & 4.00 & 4.00 \\
\hline & & & & & & & F & 0.33 & 0.00 & 0.00 & 0.11 & 0.26 & 0.22 \\
\hline & & & & & & & $\Sigma$ anions & 31.00 & 31,00 & 31.00 & 31.00 & 31.00 & 31.00 \\
\hline & & & & & & & $\Sigma$ cations & 19.90 & 20.01 & 20.03 & 19.98 & 19.98 & 20.07 \\
\hline
\end{tabular}

* Electron-microprobe data.

and to shed light on the oxidation conditions at the time of crystallization. Insufficient quantities of holotype (type-I) niobokupletskite precluded the possibility of obtaining a Mössbauer spectrum; an absorber for a sample of fibrous type-II niobokupletskite was therefore prepared by crushing an ideal mass of sample [55.1 mg, calculated using the technique of Rancourt $e t$ al. (1993)]. Crushing was done in acetone to minimize oxidation in the presence of atmospheric oxygen. The powdered niobokupletskite was suspended in petroleum jelly to ensure a random orientation of crystals within the circular aluminum mount (aperture: $1.0 \mathrm{~cm}$, thickness: $0.6 \mathrm{~cm})$.

The spectrum was obtained using a ${ }^{57} \mathrm{Co}$ source in a rhodium matrix at room temperature $\left(21^{\circ} \mathrm{C}\right)$. The transducer was employed in constant-acceleration mode over a Doppler velocity range of $\pm 4.0 \mathrm{~mm} / \mathrm{s}$, with fixed distances between the absorber and source and between the absorber and detector of 3.0 and $7.0 \mathrm{~cm}$, respectively. Spectra were calibrated with an ${ }^{57} \mathrm{Fe}$-enriched iron foil. Data were collected in 1024 channels and folded to obtain a flat background. Spectra were fitted with the Voigt-based quadrupole-splitting distribution method of Rancourt \& Ping (1991), as implemented in the program RECOIL (Lagarec \& Rancourt 1998).

The Mössbauer spectrum of niobokupletskite is shown in Figure 3, and the site-distribution parameters and associated errors, in Table 3 . The spectrum is characterized by three main absorption peaks at approximately $-0.07,0.81$ and $2.33 \mathrm{~mm} / \mathrm{s}$, corresponding to: (1) the sum of the low-energy lines from ${ }^{[6]} \mathrm{Fe}^{2+}$ and ${ }^{[6]} \mathrm{Fe}^{3+}$ doublets, (2) the high-energy lines from ${ }^{[6]} \mathrm{Fe}^{3+}$ doublets, and (3) the high-energy lines from ${ }^{[6]} \mathrm{Fe}^{2+}$ doublets, respectively. All $\mathrm{Fe}$ is found to be located in the sheet of octahedra (see below). The dominant feature in the spectrum is a wide doublet, attributable to ${ }^{[6]} \mathrm{Fe}^{2+}$ (modeled as having three Gaussian components), which has an average center shift (CS) of $1.13 \mathrm{~mm} / \mathrm{s}$ (with respect to $\alpha-\mathrm{Fe}$ at room temperature) and an average quadrupole-splitting distribution (QSD) of $2.33 \mathrm{~mm} / \mathrm{s}$. The low-energy side of this doublet displays a pronounced shoulder as a result of the presence 


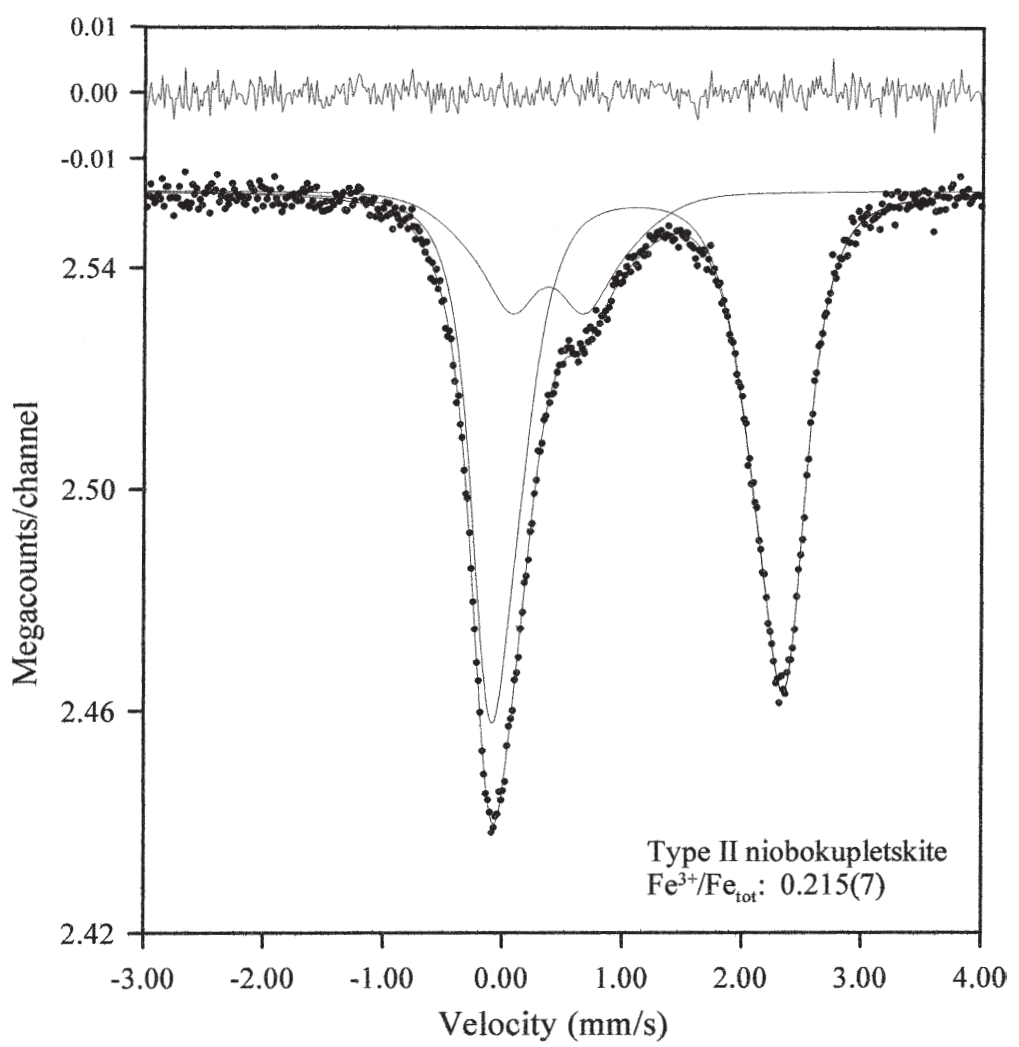

FIG. 3. Mössbauer spectrum of Type-II niobokupletskite. The solid line through the spectral data represents the best fit. The subspectral contributions corresponding to ${ }^{[6]} \mathrm{Fe}^{2+}$ and ${ }^{[6]} \mathrm{Fe}^{3+}$ are shown superimposed on the data. The difference between the observed and calculated spectrum is shown on an exaggerated vertical scale at the top of the figure.

of a second doublet (modeled as two Gaussian components), with an average CS of $0.38 \mathrm{~mm} / \mathrm{s}$ and an average QSD of $0.81 \mathrm{~mm} / \mathrm{s}$, corresponding ${ }^{[6]} \mathrm{Fe}^{3+}$. There is no evidence for ${ }^{[4]} \mathrm{Fe}^{3+}$. The resultant $\mathrm{Fe}^{3+} / \mathrm{Fe}_{\text {tot }}$ ratio

TABLE 3. MÖSSBAUER SITE DISTRIBUTION PARAMETERS FOR

\begin{tabular}{lllll}
\multicolumn{5}{c}{ TYPE-II NIOBOKUPLETSKITE } \\
\hline $\mathrm{Fe}^{2+}$ & $\delta_{0}(\mathbf{m m} / \mathbf{s})$ & $\delta_{1}$ & $\mathbf{A}($ counts·mm/s) & A. $/ \mathrm{A}_{+}$ \\
$\mathrm{Fe}^{3+}$ & $1.07(3)$ & $0.03(1)$ & $118600(1600)$ & $1^{*}$ \\
& $0.38(3)$ & $0^{*}$ & $32500(1300)$ & $1^{*}$
\end{tabular}

\begin{tabular}{|c|c|c|c|c|}
\hline & & $\underset{(\%)}{\mathbf{p}}$ & $\begin{array}{l}\langle\Delta\rangle \\
(\mathrm{mm} / \mathrm{s})\end{array}$ & $\begin{array}{l}\sigma_{\Delta} \\
(\mathrm{mm} / \mathrm{s})\end{array}$ \\
\hline \multirow[t]{3}{*}{$\mathrm{Fe}^{2+}$} & comp. 1 & 46 & $2.24(5)$ & $0.5(1)$ \\
\hline & comp. 2 & $7(15)$ & $1.98(2)$ & $0.2(2)$ \\
\hline & comp. 3 & $46(2)$ & $2.47(4)$ & $0.20(4)$ \\
\hline \multirow{3}{*}{$\mathrm{Fe}^{3+}$} & comp. 1 & 27 & $0.6(1)$ & $0.2(2)$ \\
\hline & comp. 2 & $73(3)$ & $0.8(3)$ & $0.7(1)$ \\
\hline & $\begin{array}{l}\langle\mathrm{CS}\rangle \\
(\mathrm{mm} / \mathrm{s})\end{array}$ & $\begin{array}{l}\langle|\Lambda|\rangle \\
(\mathrm{mm} / \mathrm{s})\end{array}$ & $\begin{array}{l}\text { stdev } \\
(|\Lambda|)\end{array}$ & $\begin{array}{l}\text { skew } \\
\text { (iLI) }\end{array}$ \\
\hline & 1.13 & 2.33 & 0.39 & -0.41 \\
\hline $\mathrm{Fc}^{3+}$ & 0.38 & 0.81 & 0.52 & 0.89 \\
\hline
\end{tabular}

reduced $\chi^{2}=0.96 \quad \mathrm{Fe}^{3+} \quad \mathbf{2 1 . 5 ( 7 )}$

Site populations $(\%): \mathrm{Fe}^{2+} \quad 78.5(7) \quad \mathrm{Fe}^{3+} \quad 21.5(7)$ * fixed valuc obtained from analysis of the spectral areas is $0.215(7)$, corresponding to $0.33 \mathrm{apfu} \mathrm{Fe}^{3+}$, a high value compared to those obtained for other samples of astrophyllitegroup minerals from a variety of intrusive complexes (average $\mathrm{Fe}^{3+} / \mathrm{Fe}_{\text {tot }} \approx 0.07$, P. Piilonen, unpubl. data).

\section{X-Ray Crystallography}

A chemically homogeneous grain of type-I niobokupletskite $(0.21 \times 0.19 \times 0.02 \mathrm{~mm})$ was selected from those within the electron-microprobe epoxy mount for a single-crystal X-ray-diffraction study. X-ray powderdiffraction data were collected with a $114.6 \mathrm{~mm}$ DebyeScherrer camera with $\mathrm{CuK \alpha}$ radiation (Ni-filtered), operating at $45 \mathrm{kV}$ and $20 \mathrm{~mA}$, and are presented in Table 4. X-ray intensity data were collected using the Siemens SMART (Siemens Molecule Analysis Research Tool) system at the University of Ottawa; it consists of a PLATFORM three-circle goniometer and a $1 \mathrm{~K}$ (diameter: $9 \mathrm{~cm}$ (512 pixel) charge-coupled device (CCD) area-detector. Data were collected at room temperature using monochromatic $\mathrm{MoK} \alpha \mathrm{X}$-radiation 
TABLE 4 X-RAY POWDER-DIFFRACTION DATA FOR NIOBOKUPLETSKITE

\begin{tabular}{|c|c|c|c|c|c|c|c|c|c|}
\hline$d_{\text {mcas }}$ & $d_{\mathrm{calc}}$ & $I_{o b s}$ & $I_{\mathrm{calc}}$ & $h k l$ & $d_{\text {meat }}$ & $d_{\mathrm{calc}}$ & $I_{\mathrm{abs}}$ & $I_{\text {calc }}$ & $h k l$ \\
\hline \multirow[t]{2}{*}{10.707} & 10.619 & 100 & 100 & 001 & 2.409 & 2.412 & 10 & 6 & 141 \\
\hline & 10.532 & & 38 & 010 & & 2.403 & & 6 & $\overline{134}$ \\
\hline \multirow[t]{2}{*}{9.883} & 9.826 & $<5$ & 17 & $0 \overline{11}$ & 2.322 & 2.325 & 10 & 4 & $2 \overline{1} 2$ \\
\hline & 5.829 & & $<1$ & $0 \overline{12}$ & 2.308 & 2.308 & 10 & 5 & 131 \\
\hline 5.840 & 5.785 & 5 & 12 & $0 \overline{2} 1$ & & 2.299 & & 5 & 144 \\
\hline \multirow[t]{4}{*}{4.405} & 4.432 & 20 & 10 & $\overline{111}$ & 2.254 & 2.255 & $<5$ & $<1$ & 051 \\
\hline & 4.367 & & 5 & 120 & & 2.250 & & 7 & $\overline{2} 13$ \\
\hline & 4.346 & & 3 & 101 & 2.222 & 2.223 & $<5$ & 3 & $2 \overline{4} 1$ \\
\hline & 4.335 & & 7 & $1 \overline{2} 1$ & & 2.216 & & 2 & 222 \\
\hline \multirow{2}{*}{4.100} & 4.098 & $<5$ & $<1$ & 012 & & 2.203 & & 2 & $\overline{22} 1$ \\
\hline & 4.083 & & 6 & 021 & 2.130 & 2.124 & 5 & 3 & $\overline{142}$ \\
\hline \multirow[t]{3}{*}{3.816} & 3.795 & 5 & 3 & T21 & & 2.124 & & 3 & 005 \\
\hline & 3.778 & & 2 & $1 \overline{12}$ & 2.118 & 2.118 & 5 & 1 & 140 \\
\hline & 3.761 & & 6 & $0 \overline{23}$ & & 2.115 & & 3 & 135 \\
\hline \multirow[t]{2}{*}{3.536} & 3.540 & 50 & 40 & 003 & 2.056 & 2.060 & $<5$ & 4 & $2 \overline{1} 3$ \\
\hline & 3.539 & & 10 & $1 \mathrm{I} 1$ & 2.023 & 2.025 & $<5$ & 3 & 132 \\
\hline \multirow[t]{2}{*}{3.294} & 3.281 & 20 & 13 & $\overline{113}$ & & 2.017 & & 3 & $1 \overline{45}$ \\
\hline & 3.275 & & 2 & $0 \overline{3} 3$ & 1.995 & 1.999 & $<5$ & 2 & 151 \\
\hline 3.147 & 3.137 & $<5$ & 5 & 022 & & 1.987 & & 2 & 214 \\
\hline \multirow[t]{2}{*}{3.108} & 3.099 & $<5$ & 11 & $\overline{122}$ & & 1.983 & & 2 & 232 \\
\hline & 3.046 & & $<1$ & 123 & 1.933 & 1.930 & $<5$ & 1 & 015 \\
\hline \multirow[t]{3}{*}{3.047} & 3.044 & $<5$ & 10 & $1 \overline{2} 3$ & & 1.928 & & 2 & $0 \overline{63}$ \\
\hline & 2.996 & & 5 & 013 & & 1.774 & & 7 & 133 \\
\hline & 2.993 & & 2 & $\overline{1} 31$ & 1.769 & 1.767 & 5 & 7 & $1 \overline{46}$ \\
\hline 2.988 & 2.980 & $<5$ & $<1$ & 031 & & 1.764 & & 2 & $2 \overline{6} 2$ \\
\hline \multirow[t]{4}{*}{2.887} & 2.886 & 5 & 5 & $1 \overline{3} 3$ & & 1.762 & & 1 & $3 \overline{3} 0$ \\
\hline & 2.877 & & 4 & 014 & 1.751 & 1.750 & $<5$ & 7 & $\overline{2} 15$ \\
\hline & 2.876 & & 6 & 112 & 1.660 & 1.659 & 5 & 11 & $0 \overline{73}$ \\
\hline & 2.831 & & 4 & 121 & 1.633 & 1.634 & $<5$ & 4 & 144 \\
\hline \multirow[t]{2}{*}{2.824} & 2.822 & $<5$ & 1 & $1 \overline{4} 1$ & & 1.634 & & 2 & 127 \\
\hline & 2.819 & & 2 & 132 & & 1.631 & & 2 & 240 \\
\hline \multirow[t]{2}{*}{2.793} & 2.787 & 40 & 22 & 131 & & 1.628 & & 4 & 137 \\
\hline & 2.784 & & 23 & $1 \overline{4} 2$ & & 1.628 & & 2 & $\overline{245}$ \\
\hline \multirow[t]{3}{*}{2.677} & 2.679 & 30 & 19 & $\overline{2} 11$ & 1.589 & 1.589 & 5 & 9 & $3 \overline{5} 1$ \\
\hline & 2.668 & & 3 & $\overline{114}$ & & 1.589 & & 9 & $\overline{322}$ \\
\hline & 2.655 & & 10 & 004 & 1.575 & 1.575 & $<5$ & $<1$ & $\overline{253}$ \\
\hline \multirow[t]{2}{*}{2.587} & 2.587 & 40 & 19 & 130 & & 1.575 & & $<1$ & $2 \overline{72}$ \\
\hline & 2.580 & & 18 & $1 \overline{4} 3$ & & 1.573 & & 2 & 350 \\
\hline 2.503 & 2.504 & 20 & 16 & 212 & & 1.572 & & 1 & $\overline{323}$ \\
\hline
\end{tabular}

$\mathrm{CuK} \alpha$ radiation, Ni-filtered, $45 \mathrm{kV}, 20 \mathrm{~mA}, 24$-hour exposure, Debye-Scherre camera $114.6 \mathrm{~mm}$ in radius, with intensities visually estimated. The values of $d$ are expressed in $\AA$

$(40 \mathrm{kV}, 30 \mathrm{~mA})$ and a fixed detector-crystal distance of $12.621 \mathrm{~cm}$. A frame width $(\omega)$ of $0.3^{\circ}$ and count exposure times of 30 seconds per frame were the standard setting. A hemisphere of data was collected for $4.82 \leq$ $2 \theta \leq 57.26$, with minimum and maximum indices $-7 \leq$ $h \leq 7,-11 \leq k \leq 16$, and $-15 \leq l \leq 15$. The data were reduced, filtered, integrated, and corrected for Lorentz, polarization and background effects using the Siemens program SAINT. A $\Psi$-scan data set of 724 reflections was used during absorption corrections, using the program XPREP with the crystal modeled as an ellipsoid using the program XPREP. The merging $R$ decreased from $14.14 \%$ before the absorption correction to $7.89 \%$ after the absorption correction, giving minimum and maximum transmission-factors of 0.343 and 0.664 , respectively. Phasing of a set of normalized structurefactors gave a mean value $\left|E^{2}-1\right|$ of 0.985 , suggesting the centrosymmetric space-group $P \overline{1}$, a feature consistent with other studies of triclinic astrophyllitegroup minerals (Peng \& Ma 1963, Woodrow 1967, Christiansen et al. 1998). Information pertinent to the
TABLE 5. MISCELLANEOUS DATA: NIOBOKUPLETSKITE

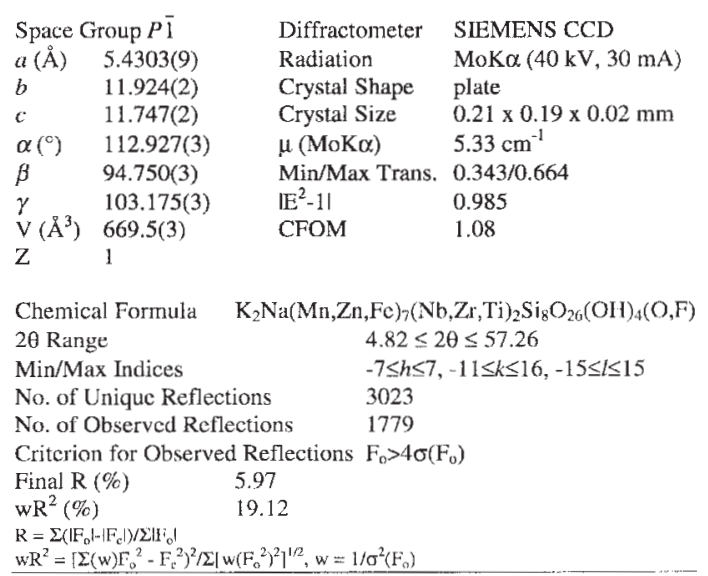

data collection and crystal structure can be found in Table 5. The structure of niobokupletskite was refined by least-squares methods using the SHELXL-93 set of programs (Sheldrick 1993), with starting parameters taken from Christiansen et al. (1998) for kupletskite from Kangerdlugssuaq, Greenland. During the initial refinement, $\mathrm{Mn}$, the dominant octahedrally coordinated cation indicated by the analytical results, was assigned to $M(1)-M(4)$, whereas $\mathrm{Nb}$ was assigned to the $D$ site on the basis of the analytical data. Refinement of the site-occupancy factors resulted in values less than unity for $M(1)$ and $D$, and values greater than unity for $M(2)$, $M(3)$, and $M(4)$. Sodium was assigned to $M(1)$, and Ti was assigned to $D$. Zinc, a heavier X-ray scatterer than Mn and the second most abundant element in $C$ according to the electron-microprobe data, was assigned to $M(2), M(3)$ and $M(4)$; the pattern of order of $\mathrm{Zn}$ over these four sites is discussed below. The shape of the anisotropic displacement ellipsoid of the site to which $\mathrm{K}$ is assigned suggests that it is positionally disordered; it was therefore modeled as two split sites, ${ }^{[9]} K(1 \mathrm{a})$ and ${ }^{[10]} K(1 \mathrm{~b})$, displaced $0.36 \AA$ from each other along $X$. Displacement factors for $K(1 \mathrm{a})$ and $K(1 \mathrm{~b})$ were constrained to be equal and refined isotropically. The structure refined to $R=9.40 \%$ and $\mathrm{w} R^{2}=26.11 \%$ with isotropic displacement factors, and to $R=5.97 \%$ and $\mathrm{w} R^{2}=19.22 \%$ with anisotropic displacement factors. An isotropic extinction correction was applied but did not improve the results. The high final $R$ value is attributable to slippage along the $\{001\}$ cleavage, imposed during extraction of the crystal from the epoxy mount, and also to microfractures observed in the crystal in BSE images (Fig. 1A). The final positional and isotropic displacement parameters are given in Table 6 , and selected bond-lengths are given in Table 7. Bond-valence sums were calculated using parameters taken from Brese \& O'Keeffe (1991) and can be found in Table 8. The observed and calculated structure-factors are available 
TABLE 6. POSITIONAL AND DISPLACEMENT PARAMETERS AND SITE OCCUPANCIES FOR NIOBOKUPLETSKITE

\begin{tabular}{|c|c|c|c|c|c|c|c|c|c|c|c|}
\hline Atom & $x$ & $y$ & $z$ & $s o f$ & $U_{11}$ & $U_{22}$ & $U_{33}$ & $U_{23}$ & $U_{13}$ & $U_{12}$ & $U_{\mathrm{eq}}$ \\
\hline $\operatorname{Mn}(1)$ & $0.8511(3)$ & $0.2057(2)$ & $0.4794(2)$ & $0.91(1)$ & $26(9)$ & $138(11)$ & $163(11)$ & $67(8)$ & $27(7)$ & $31(7)$ & $106(6)$ \\
\hline $\mathrm{Na}$ & $0.8511(3)$ & $0.2057(2)$ & $0.4794(2)$ & $0.09(1)$ & $26(9)$ & $138(11)$ & $163(11)$ & $67(8)$ & $27(7)$ & $31(7)$ & $106(6)$ \\
\hline $\operatorname{Mn}(2)$ & $0.2790(3)$ & $0.0680(2)$ & $0.4871(1)$ & $0.90(3)$ & $38(8)$ & $164(11)$ & $174(10)$ & $91(8)$ & $44(6)$ & $39(7)$ & $115(6)$ \\
\hline $\mathrm{Zn}(2)$ & $0.2790(3)$ & $0.0680(2)$ & $0.4871(1)$ & $0.10(3)$ & $38(8)$ & $164(11)$ & $174(10)$ & $91(8)$ & $44(6)$ & $39(7)$ & $115(6)$ \\
\hline $\operatorname{Mn}(3)$ & $0.4211(3)$ & $0.3512(2)$ & $0.4844(1)$ & $0.85(3)$ & $43(8)$ & $154(11)$ & $185(10)$ & $88(8)$ & $43(6)$ & $35(7)$ & $119(6)$ \\
\hline $\mathrm{Zn}(3)$ & $0.4211(3)$ & $0.3512(2)$ & $0.4844(1)$ & $0.15(3)$ & $43(8)$ & $154(11)$ & $185(10)$ & $88(8)$ & $43(6)$ & $35(7)$ & $119(6)$ \\
\hline $\operatorname{Mn}(4)$ & 0 & 0.5 & 0.5 & $0.33(2)$ & $13(10)$ & $131(14)$ & $166(13)$ & $55(10)$ & $20(8)$ & $-4(9)$ & $110(8)$ \\
\hline $\mathrm{Zn}(4)$ & 0 & 0.5 & 0.5 & $0.17(2)$ & $13(10)$ & $131(14)$ & $166(13)$ & $55(10)$ & $20(8)$ & $-4(9)$ & $110(8)$ \\
\hline $\mathrm{Nb}$ & $0.0749(2)$ & $0.0818(1)$ & $0.1865(1)$ & $0.90(1)$ & $4(5)$ & $133(6)$ & $178(6)$ & $77(5)$ & $37(4)$ & $26(4)$ & $100(4)$ \\
\hline $\mathrm{Ti}$ & $0.0749(2)$ & $0.0818(1)$ & $0.1865(1)$ & $0.10(1)$ & $4(5)$ & $133(6)$ & $178(6)$ & $77(5)$ & $37(4)$ & $26(4)$ & $100(4)$ \\
\hline $\operatorname{Si}(1)$ & $0.6786(6)$ & $0.2745(3)$ & $0.2314(3)$ & 1.00 & $68(14)$ & $186(18)$ & $154(16)$ & $103(14)$ & $45(11)$ & $60(12)$ & $120(7)$ \\
\hline $\mathrm{Si}(2)$ & $0.8133(6)$ & $0.5470(3)$ & $0.2526(3)$ & 1.00 & $95(14)$ & $136(17)$ & $146(16)$ & $76(14)$ & $23(12)$ & $24(13)$ & $122(7)$ \\
\hline $\mathrm{Si}(3)$ & $0.3765(6)$ & $0.6737(3)$ & $0.2552(3)$ & 1.00 & $89(15)$ & $167(18)$ & $149(16)$ & $84(14)$ & $9(11)$ & $18(13)$ & $133(7)$ \\
\hline $\operatorname{Si}(4)$ & $0.5070(5)$ & $0.9296(3)$ & $0.2362(3)$ & 1.00 & $49(14)$ & $108(16)$ & $139(15)$ & $47(14)$ & 21(11) & $18(12)$ & $103(7)$ \\
\hline$K(1 a)$ & $0.097(6)$ & $0.278(1)$ & & $0.41(6)$ & & & & & & & $433(17)$ \\
\hline $\mathrm{K}(1 \mathrm{~b})$ & $0.164(4)$ & $0.2754(8)$ & $0.9956(8)$ & $0.48(6)$ & & & & & & & $433(17)$ \\
\hline $\mathrm{Rb}(1 \mathrm{~b})$ & $0.164(4)$ & $0.2754(8)$ & $0.9956(8)$ & 0.065 & & & & & & & $433(17)$ \\
\hline $\mathrm{Na}$ & 0.5 & 0 & 0 & 0.45 & $148(39)$ & $200(46)$ & $147(39)$ & $46(33)$ & $-11(28)$ & $33(29)$ & $179(24)$ \\
\hline$O(1)$ & $0.728(1)$ & $0.3194(7)$ & $0.3832(7)$ & 1.00 & $28(33)$ & $226(45)$ & $165(39)$ & $102(37)$ & $33(29)$ & $73(32)$ & $126(16)$ \\
\hline $\mathrm{O}(2)$ & $0.146(1)$ & $0.1600(8)$ & $0.3682(7)$ & 1.00 & $134(40)$ & $167(45)$ & $176(41)$ & $74(37)$ & $21(32)$ & $45(35)$ & $158(17)$ \\
\hline$O(3)$ & $0.130(1)$ & $0.3931(7)$ & $0.5949(6)$ & 1.00 & & & & & & & $88(15)$ \\
\hline $\mathrm{OH}(4)$ & $0.295(1)$ & $0.4631(8)$ & $0.3991(7)$ & 1.00 & $102(36)$ & $210(44)$ & $146(38)$ & $84(36)$ & $74(30)$ & $114(34)$ & $134(16)$ \\
\hline $\mathrm{OH}(5)$ & $0.993(1)$ & $0.1179(7)$ & $0.5944(7)$ & 1.00 & $104(37)$ & $133(42)$ & $142(38)$ & $23(35)$ & $67(30)$ & $13(32)$ & $139(16)$ \\
\hline$O(6)$ & $0.559(1)$ & $0.2576(7)$ & $0.5915(6)$ & 1.00 & $24(32)$ & $161(42)$ & $107(36)$ & $60(34)$ & $24(28)$ & $19(30)$ & $96(16)$ \\
\hline$O(7)$ & $0.573(1)$ & $0.0134(7)$ & $0.386 .5(7)$ & 1.00 & $37(33)$ & $74(39)$ & $184(40)$ & $61(34)$ & $0(29)$ & $-11(29)$ & $102(16)$ \\
\hline$O(8)$ & $0.072(2)$ & $0.5915(8)$ & $0.2004(7)$ & 1.00 & $184(43)$ & $284(52)$ & $222(47)$ & $91(43)$ & $131(37)$ & $36(39)$ & $235(20)$ \\
\hline$O(9)$ & $0.250(2)$ & $0.043(1)$ & $0.8260(9)$ & 1.00 & $268(53)$ & $597(76)$ & $210(49)$ & $30(51)$ & $51(42)$ & $-337(52)$ & $486(33)$ \\
\hline$O(10)$ & $0.433(2)$ & $0.4144(8)$ & $0.7988(7)$ & 1.00 & $215(46)$ & $359(57)$ & $186(46)$ & $98(44)$ & $22(37)$ & $116(42)$ & $254(21)$ \\
\hline$O(11)$ & $0.129(2)$ & $0.803(1)$ & $0.8297(9)$ & 1.00 & $683(78)$ & $595(75)$ & $238(52)$ & $182(55)$ & $22(51)$ & $534(67)$ & $431(29)$ \\
\hline $\mathrm{O}(12)$ & $0.267(2)$ & $0.954(1)$ & $0.1723(9)$ & 1.00 & $709(79)$ & $516(72)$ & $185(49)$ & $-78(45)$ & $-189(50)$ & $526(65)$ & $498(35)$ \\
\hline$O(13)$ & $0.266(2)$ & $0.6062(8)$ & $0.8075(8)$ & 1.00 & $508(63)$ & $106(45)$ & $140(41)$ & $18(37)$ & $35(39)$ & $77(45)$ & $266(22)$ \\
\hline$O(14)$ & $0.571(2)$ & $0.2206(8)$ & $0.8024(8)$ & 1.00 & $568(66)$ & $88(45)$ & $206(46)$ & $58(40)$ & $29(44)$ & $-14(45)$ & $311(24)$ \\
\hline$O(15)$ & $0.385(2)$ & $0.197(1)$ & $0.1693(8)$ & 1.00 & $308(55)$ & $559(74)$ & $240(50)$ & $202(53)$ & $-56(43)$ & $-247(52)$ & $431(30)$ \\
\hline $\mathrm{O}(16)$ & 0 & 0 & 0 & 0.50 & $76(52)$ & $277(72)$ & $213(62)$ & $121(54)$ & $65(42)$ & $96(47)$ & $172(35)$ \\
\hline
\end{tabular}

from the Depository of Unpublished Data, CISTI, National Research Council of Canada, Ottawa, Ontario K1A 0S2, Canada.

\section{Description of the Structure}

Astrophyllite-group minerals are generally triclinic (but also monoclinic) alkali titano-, zircono-, and niobosilicates that occur in $\mathrm{SiO}_{2}$-oversaturated- and undersaturated alkaline rocks ranging in composition from alkali granites to peralkaline nepheline syenites. The crystal structure of astrophyllite was first determined by Peng \& Ma (1963) and later elaborated on by Woodrow (1967). Since then, structural studies of members of the astrophyllite group have been performed by Christiansen et al. (1998; kupletskite) and Shi et al. (1998; 
TABLE 7. SELECTED INTERATOMIC DISTANCES $(\AA)$ FOR NIOBOKUPLETSKITE

\begin{tabular}{|c|c|c|c|}
\hline$M(1)-\mathrm{O}(2)$ & $2.179(8)$ & $T(1)-O(11)$ & $1.585(9)$ \\
\hline$M(1)-\mathrm{O}(6)$ & $2.190(7)$ & $T(1)-\mathrm{O}(15)$ & $1.595(9)$ \\
\hline$M(1)-\mathrm{OH}(5)$ & $2.194(8)$ & $T(1)-O(1)$ & $1.628(8)$ \\
\hline$M(1)-O(3)$ & $2.209(7)$ & $T(1)-O(13)$ & $1.631(9)$ \\
\hline$M(1)-\mathrm{O}(7)$ & $2.221(7)$ & $\langle T(1)-\mathrm{O}\rangle$ & 1.604 \\
\hline$M(1)-\mathrm{O}(1)$ & $2.247(7)$ & & \\
\hline \multirow[t]{2}{*}{$\langle M(1)-\mathrm{O}\rangle$} & 2.207 & $T(2)-O(13)$ & $1.614(9)$ \\
\hline & & $T(2)-\mathrm{O}(3)$ & $1.620(7)$ \\
\hline$M(2)-\mathrm{OH}(5)$ & $2.124(7)$ & $T(2)-O(8)$ & $1.638(8)$ \\
\hline$M(2)-\mathrm{O}(7)$ & $2.133(8)$ & $T(2)-\mathrm{O}(10)$ & $1.654(8)$ \\
\hline$M(2)-\mathrm{OH}(5)$ & $2.152(8)$ & $\langle T(2)-\mathrm{O}\rangle$ & 1.629 \\
\hline$M(2)-O(6)$ & $2.211(7)$ & & \\
\hline$M(2)-\mathrm{O}(2)$ & $2.252(8)$ & $T(3)-O(6)$ & $1.629(7)$ \\
\hline$M(2)-\mathrm{O}(7)$ & $2.254(7)$ & $T(3)-O(14)$ & $1.630(9)$ \\
\hline \multirow[t]{2}{*}{$<\mathrm{M} 2-\mathrm{O}\rangle$} & 2.188 & $T(3)-O(10)$ & $1.630(9)$ \\
\hline & & $T(3) \cdot \mathrm{O}(8)$ & $1.645(8)$ \\
\hline$M(3)-\mathrm{O}(1)$ & $2.143(7)$ & $\langle T(3)-O\rangle$ & 1.634 \\
\hline$M(3)-\mathrm{OH}(4)$ & $2.145(7)$ & & \\
\hline$M(3)-\mathrm{O}(3)$ & $2.151(7)$ & $T(4)-O(9)$ & $1.591(9)$ \\
\hline$M(3)-O(6)$ & $2.169(7)$ & $T(4)-O(12)$ & $1.591(9)$ \\
\hline$M(3)-\mathrm{OH}(4)$ & $2.210(8)$ & $T(4)-O(14)$ & $1.607(9)$ \\
\hline $\mathrm{M}(3)-\mathrm{O}(2)$ & $2.232(8)$ & $T(4)-O(7)$ & $1.613(8)$ \\
\hline$\langle\mathrm{M}(3)-\mathrm{O}\rangle$ & 2.175 & $\langle T(4)-O\rangle$ & 1.601 \\
\hline$M(4)-\mathrm{OH}(4)$ & $2.097(7) \times 2$ & $K(1 \mathrm{a})-O(12)$ & $2.83(2)$ \\
\hline$M(4)-\mathrm{O}(1)$ & $2.149(8) \times 2$ & $K(1 a)-O(11)$ & $2.85(2)$ \\
\hline$M(4)-O(3)$ & $2.181(7) \times 2$ & $K(1 \mathrm{a})-\mathrm{O}(15)$ & $3.04(2)$ \\
\hline \multirow[t]{2}{*}{$\langle M(4)-O\rangle$} & 2.142 & $K(1 \mathrm{a})-O(9)$ & $3.07(2)$ \\
\hline & & $K(1 \mathrm{a})-\mathrm{O}(14)$ & $3.25(3)$ \\
\hline$D-O(2)$ & $1.929(8)$ & $K(1 \mathrm{a})-\mathrm{O}(16)$ & $3.26(1)$ \\
\hline$D-\mathrm{O}(16)$ & $1.981(1)$ & $K(1 \mathrm{a}) \mathrm{O}(13)$ & $3.27(3)$ \\
\hline$D-O(9)$ & $1.987(8)$ & $K(1 \mathrm{a})-\mathrm{O}(8)$ & $3.41(2)$ \\
\hline$D-O(15)$ & $1.994(8)$ & $\langle K(1 \mathrm{a})-O\rangle$ & 3.12 \\
\hline$D-\mathrm{O}(12)$ & $1.998(9)$ & & \\
\hline$D-O(11)$ & $2.001(9)$ & $K(1 \mathrm{~b}) \mathrm{O}(15)$ & $2.84(2)$ \\
\hline \multirow[t]{2}{*}{$\langle D-\mathrm{O}\rangle$} & 1.982 & $K(1 \mathrm{~b})-\mathrm{O}(9)$ & $2.88(2)$ \\
\hline & & $K(1 \mathrm{~b})-\mathrm{O}(12)$ & $2.99(2)$ \\
\hline $\mathrm{Na}-\mathrm{O}(12)$ & $2.64(1) \times 2$ & $K(1 \mathrm{~b})-\mathrm{O}(11)$ & $3.00(2)$ \\
\hline $\mathrm{Na}-\mathrm{O}(9)$ & $2.64(1) \times 2$ & $K(1 \mathrm{~b})-O(16)$ & $3.224(9)$ \\
\hline $\mathrm{Na}-\mathrm{O}(11)$ & $2.66(1) \times 2$ & $K(1 \mathrm{~b})-O(14)$ & $3.29(2)$ \\
\hline $\mathrm{Na}-\mathrm{O}(15)$ & $2.66(1) \times 2$ & $K(1 \mathrm{~b})-\mathrm{O}(13)$ & $3.35(2)$ \\
\hline $\mathrm{Na}-\mathrm{O}(16)$ & $2.715(0) \times 2$ & $K(1 b)-O(10)$ & $3.56(1)$ \\
\hline \multirow[t]{2}{*}{$<\mathrm{Na}-\mathrm{O}\rangle$} & 2.66 & $K(1 \mathrm{~b})-\mathrm{O}(8)$ & $3.57(2)$ \\
\hline & & $\langle K(\mathrm{Ib})-\mathrm{O}\rangle$ & 3.19 \\
\hline
\end{tabular}

monoclinic magnesium astrophyllite). All triclinic species have the general formula $A_{2} B C_{7} D_{2} T_{8} \mathrm{O}_{26}(\mathrm{OH})_{4}(\mathrm{~F}$, $\mathrm{O}, \mathrm{OH})$, where $A={ }^{[13]} \mathrm{K}, \mathrm{Rb}, \mathrm{Cs}, \square$ or $\mathrm{H}_{3} \mathrm{O} ; B={ }^{[10]} \mathrm{Na}$ and $\mathrm{Ca} ; C=$ four distinct octahedrally coordinated sites $[M(1), M(2), M(3)$ and $M(4)], D={ }^{[6]} \mathrm{Ti}, \mathrm{Nb}$ or $\mathrm{Zr}$, and $T$ $={ }^{[4]} \mathrm{Si}$ and Al. Following a modular approach applied to structures of similar titanosilicates (i.e., nafertisite, lamprophyllite), Ferraris et al. (1996) have described astrophyllite-group minerals as heterophyllosilicates having a $\mathrm{HOH}$-structure (Fig. 4) consisting of a sheet of close-packed octahedra ( $O$-sheet; Fig. 5), composed of $\mathrm{MnO}_{6}, \mathrm{FeO}_{6}, \mathrm{NaO}_{6}$ or $\mathrm{MgO}_{6}$ octahedra, sandwiched between two heterogeneous sheets ( $H$-sheets). The $H$-sheet consists of open-branched zweier single chains of $\left[\mathrm{Si}_{4} \mathrm{O}_{12}\right]^{8-}$ (Liebau 1985) running parallel to $X$, which are in turn cross-linked by corner-sharing $D \mathrm{O}_{6}$ octahedra ( $D: \mathrm{Nb}, \mathrm{Ti}, \mathrm{Zr}$ ) (Fig. 6). Individual $D \mathrm{O}_{6}$ octahedra are linked across the interlayer via a common apical anion $[\mathrm{O}(16)$, special position $1 a(0,0,0)]$. A misfit exists be- tween the $O$ - and $H$-sheets, resulting in tilting and rotation of $\mathrm{SiO}_{4}$ tetrahedra and distortion or corrugation of the $O$-sheet. The degree to which this misfit occurs is directly dependent on the composition of the $O$-sheet and decreases with increasing size of the $O$-sheet cations (Woodrow 1967, Christiansen et al. 1998, Shi et al. 1998).

\section{The interlayer}

The interlayer of niobokupletskite contains both $\mathrm{Na}$ and $\mathrm{K}$ in two distinct sites. Sodium is [10]-coordinated and located between bridging apices of the $\mathrm{NbO}_{6}$ octahedra. Bond lengths range from 2.64(1) to 2.715(0) $\AA$. Refinement of the site-occupancy factor gives 0.90 , suggesting the presence of vacancies or of a lighter scatterer (e.g., $\mathrm{H}_{2} \mathrm{O}, \mathrm{H}_{3} \mathrm{O}^{+}$). Electron-microprobe data indicate $1.23 \mathrm{apfu}$ of $\mathrm{Na}$ in niobokupletskite, suggesting an "excess" of $\mathrm{Na}$ if compared with results obtained from the structure refinement. This excess $\mathrm{Na}$ has been accounted for in the $M(1)$ octahedral site. Substitution of $\mathrm{Ca}$ for $\mathrm{Na}$ within the interlayer is common in more Fe-rich astrophyllite-group minerals (e.g., Christiansen et al. 1998), but was not detected in type-I niobokupletskite. Bond lengths to the two split sites to which $\mathrm{K}$ is assigned are as follows: ${ }^{[9]} K(1 \mathrm{a}) 2.83(2)$ to $3.41(2) \AA$, ${ }^{[10]} K(1 \mathrm{~b}) 2.84(2)$ to $3.57(2) \AA$. A high site-occupancy factor for $K(1 \mathrm{~b})(0.62)$ indicates the presence of a heavier scatterer. Rubidium, determined by electronmicroprobe analysis to be $0.13 a p f u$, was therefore assigned to this site.

\section{The $O$ sheet}

The $O$ sheet of niobokupletskite is identical to that in kupletskite, except for additional $\mathrm{Zn}, \mathrm{Fe}, \mathrm{Na}$ and $\mathrm{Mg}$. In the largest and least distorted of the four octahedra, $M(1)$, the $M$ cation is coordinated by five $\mathrm{O}^{2-}$ and one $\mathrm{OH}^{-}[\mathrm{OH}(5)]$, with a $\langle M(1)-\mathrm{O}\rangle$ distance of $2.207 \AA$ [volume: $13.990 \AA^{3}$, calculated in IVTON (Balić-Žunić \& Vickovic 1996); distortion ( $\Delta$ ): 1.041, calculated using the equation for quadratic elongation (Brown \& Shannon 1973)]. The $M(1)$ site in niobokupletskite is slightly larger than that of kupletskite $(\langle M(1)-\mathrm{O}\rangle: 2.203$ $\AA$, volume: $13.858 \AA^{3}$; Christiansen et al. 1998) owing to the presence of Na. Site-scattering refinements (SREF) of $M(1)$ consistently yielded occupancies less than unity, indicating the presence of a weaker scatterer or of vacancies. Electron-microprobe data, and a low site-occupancy factor for the site assigned to $\mathrm{Na}$, indicate an "excess" of Na. The occupancy of $M(1)$ was therefore refined with both $\mathrm{Mn}$ and $\mathrm{Na}$, resulting in site populations consistent with the EMPA data (SREF: 0.18 $a p f u$, EMPA: $0.28 a p f u$ ) and a bond-valence sum of 1.95 $v u$. The presence of Na within the $M(1)$ site is not an uncommon feature in astrophyllite-group minerals. For example, magnesium astrophyllite (Shi et al. 1998), which is monoclinic, exhibits a dominance of $\mathrm{Na}$ within 
TABLE 8. EMPIRICAL BOND-VALENCES $(v u)$ FOR NIOBOKUPLETSKITE*

\begin{tabular}{|c|c|c|c|c|c|c|c|c|c|c|c|c|c|}
\hline & $M(1)$ & $M(2)$ & $M(3)$ & $M(4)$ & $D$ & $T(1)$ & $T(2)$ & $T(3)$ & $T(4)$ & $\mathrm{Na}$ & $K(1 \mathrm{a})$ & $K(1 \mathrm{~b})$ & $\Sigma$ \\
\hline$\overline{O(1)}$ & 0.29 & & 0.36 & $0.35^{\mathrm{X}} \mathrm{z}$ & & 0.99 & & & & & & & 1.99 \\
\hline$O(2)$ & 0.35 & 0.28 & 0.28 & & 0.95 & & & & & & & & 1.86 \\
\hline $\mathrm{O}(3)$ & 0.32 & & 0.36 & $0.32^{X_{2}}$ & & & 1.01 & & & & & & 2.01 \\
\hline $\mathrm{OH}(4)$ & & & 0.67 & $0.41^{\mathrm{X}}$ & & & & & & & & & 1.08 \\
\hline $\mathrm{OH}(5)$ & 0.34 & 0.76 & & & & & & & & & & & 1.10 \\
\hline$O(6)$ & 0.34 & 0.31 & 0.35 & & & & & 0.99 & & & & & 1.99 \\
\hline$O(7)$ & 0.31 & 0.66 & & & & & & & 1.03 & & & & 2.00 \\
\hline$O(8)$ & & & & & & & 0.96 & 0.94 & & & 0.01 & 0.01 & 1.92 \\
\hline$O(9)$ & & & & & 0.79 & & & & 1.09 & $0.10^{x} \geq$ & 0.03 & 0.07 & 2.08 \\
\hline$O(10)$ & & & & & & & 0.92 & 0.98 & & & & 0.02 & 1.92 \\
\hline$O(11)$ & & & & & 0.76 & 1.11 & & & & $0.10^{\mathrm{X}}$ & 0.06 & 0.06 & 2.09 \\
\hline$O(12)$ & & & & & 0.71 & & & & 1.09 & $0.10^{x}$ & 0.06 & 0.05 & 2.01 \\
\hline$O(13)$ & & & & & & 0.98 & 1.03 & & & & 0.02 & 0.03 & 2.06 \\
\hline$O(14)$ & & & & & & & & 0.98 & 1.05 & & 0.02 & 0.04 & 2.09 \\
\hline$O(15)$ & & & & & 0.78 & 1.08 & & & & $0.10^{X_{2}}$ & 0.03 & 0.08 & 2.07 \\
\hline$O(16)$ & & & & & $0.81 \stackrel{3}{\rightarrow}$ & & & & & $0.08 \sqrt{3}$ & $0.02^{\times 2}$ & $0.02^{x_{3}} \rightarrow$ & 1.86 \\
\hline$\Sigma$ & 1.95 & 2.01 & 2.02 & 2.16 & 4.80 & 4.16 & 3.92 & 3.89 & 4.26 & 0.96 & 0.25 & 0.38 & \\
\hline
\end{tabular}

a single octahedrally coordinated site equivalent of $M(1)$ in the triclinic species; this dominance has also been noted in other astrophyllite-group minerals from Mont Saint-Hilaire (P. Piilonen, unpubl. data). Substitution of $\mathrm{Na}$ for $\mathrm{Mn}$ in octahedral coordination, although not common, also has been noted in other minerals, including samuelsonite (Moore \& Araki 1977), barytolamprophyllite (Rastsvetaeva \& Dorfman 1995), vuonnemite (Ercit et al. 1998), and in alkali clinoamphiboles from Mont Saint-Hilaire (Taylor 1999). This phenomenon may be attributable to high activities of $\mathrm{Na}$ within the crystallizing magma.

The $M(2), M(3)$ and $M(4)$ sites are larger and less distorted than those observed in kupletskite, probably owing to the increased extent of substitution of Mn for $\mathrm{Fe}$ in niobokupletskite. The $M(2)$ and $M(3)$ sites have a cis configuration $[M(2): \mathrm{OH}(5) \times 2, M(3): \mathrm{OH}(4) \times 2]$, with average $\langle M-\mathrm{O}\rangle$ distances of 2.188 and $2.175 \AA$ respectively, whereas $M(4)$ is a trans site $[\mathrm{OH}(4) \times 2]$, with an average $\langle M(4)-\mathrm{O}\rangle$ distance of $2.142 \AA$. The $M(2)$ octahedra, the most distorted in the $O$-sheet of astrophyllite-group minerals ( $\Delta: 6.059)$, are unusual, as they form continuous zigzag chains parallel to the $X$ axis; all other $M$ sites share at most one common edge with crystallographically equivalent octahedra (Fig. 5). The combination of continuous chains of $M(2)$ octahedra and open-branched zweier single chains parallel to $X$ in the $\mathrm{H}$-sheet has a pronounced effect on the mor- phology of astrophyllite-group minerals: a preferential elongation of crystals in the $X$ direction, the development of a secondary, moderate parting along $\{010\}$, and the formation of acicular to tabular crystals.

Site-scattering refinements indicate departures from ideal $\mathrm{Mn}$ occupancies and the presence of a stronger X-ray scatterer in all of $M(2), M(3)$ and $M(4)$. Zinc, the second most abundant octahedrally coordinated cation recorded in the EMPA data, was refined in all three of these sites, with the total site-occupancy constrained to be unity. Zinc populations are as follows: $M(2) 0.10$, $M(3) 0.15, M(4) 0.34$, resulting in a total $\mathrm{Zn}$ content in agreement with that obtained by electron microprobe (SREF: 0.84, EMPA: 0.73 apfu). Bond-valence sums indicate these site-occupancy factors to be reasonable [M(2): $2.01 v u, M(3): 2.02 v u, M(4): 2.16 v u]$. Results of this refinement suggest that $\mathrm{Zn}$, a cation significantly smaller than $\mathrm{Mn}\left({ }^{[6]} \mathrm{Zn}^{2+}: 0.74 \AA,{ }^{[6]} \mathrm{Mn}^{2+}: 0.83 \AA\right.$; Shannon 1976) preferentially orders at $M(4)$, the smallest of the four $M$ sites [volumes: $M(2)$ 13.687, $M(3)$ $\left.13.460, M(4) 12.902 \AA^{3}\right]$.

\section{The H-sheet}

There are four distinct tetrahedrally coordinated sites $(T)$ in the niobokupletskite structure. As EMPA results reveal only minor $\mathrm{Al}^{3+}$ (average: $0.34 a p f u$ ), and Mössbauer spectroscopy did not indicate ${ }^{[4]} \mathrm{Fe}^{3+}$, all four 


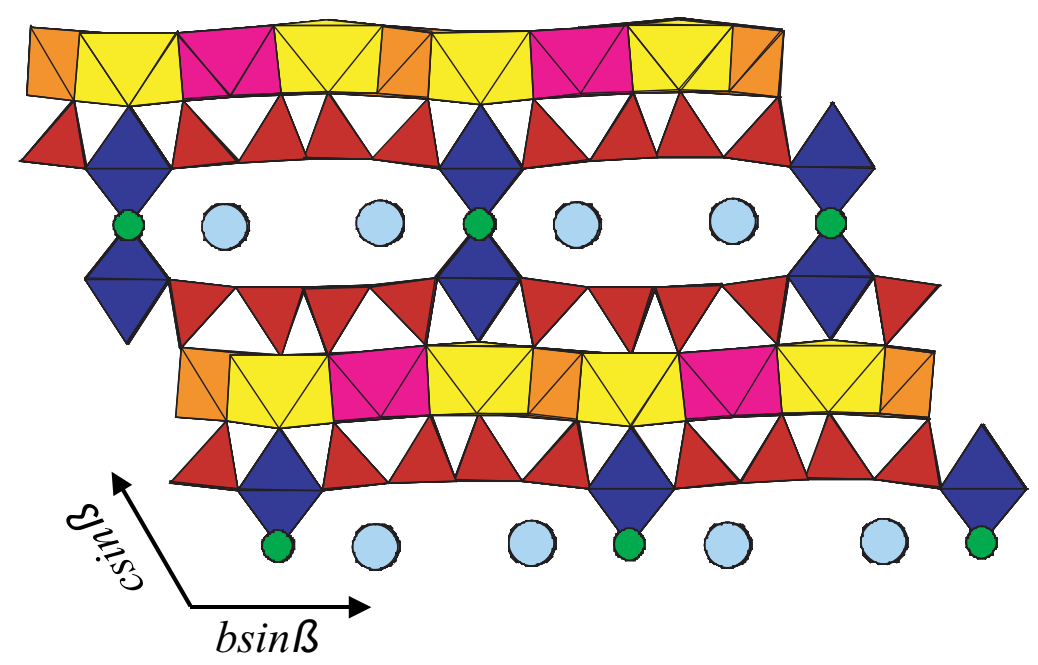

FIG. 4. The structure of niobokupletskite showing the $\mathrm{HOH}$ structure and interlayer cations (K light blue, Na green). The coloring of the polyhedra are as follows: $T$ red, $D$ dark blue, $M(1)$ yellow, $M(2)$ orange, $M(4)$ deep pink. Note that $M(3)$ is not observed in this projection.

$T$ sites were modeled with only $\mathrm{Si}^{4+}$ during the structure refinement. Bond lengths within the four tetrahedral sites range from 1.585(9) to 1.654(8) $\AA$. In niobokupletskite, $T(1)$ and $T(4)$ each share two basal, nonbridging (nb) oxygen atoms with the basal plane of the $\mathrm{NbO}_{6}$ octahedra [T(1): $\mathrm{O}(15), \mathrm{O}(11)$ and $T(4): \mathrm{O}(9)$, $\mathrm{O}(12)]$. Shorter bond-lengths to these basal oxygen atoms $\left(<T(1)-\mathrm{O}_{\mathrm{nb}}>1.590 \AA,<T(4)-\mathrm{O}_{\mathrm{nb}}>1.591 \AA\right)$ result in a tilting of $T(1)$ and $T(4) 7.73^{\circ}$ and $7.65^{\circ}$ out of the

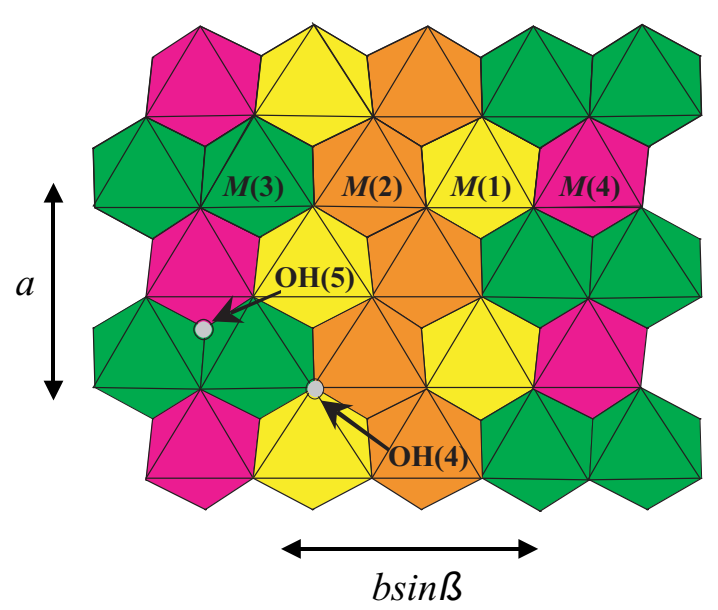

FIG. 5. The $O$-sheet of niobokupletskite showing the individual $M$ octahedra. Note the continuous zigzag chains of $M(2)$ octahedra (orange) parallel to the $X$ axis $(a)$.
(001) plane, respectively, toward the $\mathrm{NbO}_{6}$ octahedra. However, the $T(2)$ and $T(3)$ bridging tetrahedra, which do not share common oxygen atoms with the $\mathrm{NbO}_{6}$ octahedra, are tilted only 7.11 and $7.05^{\circ}$ out of the (001) plane, respectively, and display slightly longer basal $<T-\mathrm{O}>$ bond lengths than $T(1)$ and $T(4)\left(<T(2)-\mathrm{O}_{\text {basal }}>\right.$ $\left.1.629 \AA,<T(3)-\mathrm{O}_{\text {basal }}>1.635 \AA\right)$.

In niobokupletskite, bond valence sums (Table 8) indicate the presence of a divalent anion in the $\mathrm{O}(16)$

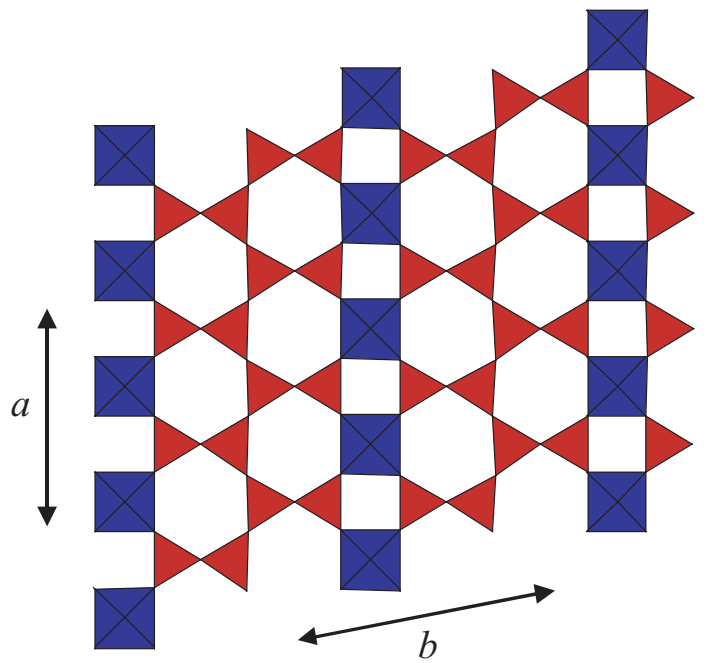

FIG. 6. The $H$-sheet of niobokupletskite showing openbranched zweier single chains of $\left[\mathrm{Si}_{4} \mathrm{O}_{12}\right]^{8-}$ parallel to the $X$ axis (a) (red) cross-linked by $\mathrm{NbO}_{6}$ octahedra (blue). 
position $(1.86 v u)$, unlike Ti-dominant astrophyllitegroup minerals, for which bond-valence calculations indicate a monovalent anion $(\mathrm{OH}$ or $\mathrm{F}$ : Christiansen et al. 1998). The incorporation of $\mathrm{O}^{2-}$ at the $\mathrm{O}(16)$ position is required in order to balance the excess positive charge attributable to $\mathrm{Nb}^{5+}$ resulting from the $\mathrm{Nb}^{5+} \Leftrightarrow \mathrm{Ti}^{4+}$ substitution. The following coupled substitution is therefore suggested for the incorporation of $\mathrm{Nb}^{5+}$ into the structure:

$$
\mathrm{Ti}^{4+}+\mathrm{F}^{-} \text {or } \mathrm{OH}^{-} \Leftrightarrow \mathrm{Nb}^{5+}+\mathrm{O}^{2-}
$$

The same mechanism of substitution has been suggested for the incorporation of $\mathrm{Ti}$ and $\mathrm{F}$ into the wöhlerite structure (Mellini \& Merlino 1979). The presence of $\mathrm{O}^{2-}$ at the $\mathrm{O}(16)$ position results in a local increase in symmetry along $Z$ within the $D_{6}$ octahedra due to the presence of a strong $\mathrm{O}(2)-\mathrm{Nb}-\mathrm{O}(16)$ bond rather than the weaker, asymmetrical $\mathrm{O}(2)-\mathrm{Ti}-\mathrm{F}$ bond observed in Ti-dominant astrophyllite-group minerals. The subsequent shortening of $D-\mathrm{O}(16)$ and lengthening of $D-\mathrm{O}(2)$ are direct results of Nb being positionally more central within the polyhedra, rather than being displaced along $Z$ toward the $O$-layer, as is the case with Ti-dominant polyhedra (P. Piilonen, unpubl. data). The $\left.<\mathrm{O}(16)-D-\mathrm{O}_{\text {basal }}\right\rangle$ bond angles are increased $\left[85.4^{\circ}\right.$, niobokupletskite; $80.8^{\circ}$, kupletskite (Christiansen et al. $1998)]$ and $\left\langle\mathrm{O}(2)-D-\mathrm{O}_{\text {basal }}\right\rangle$ are decreased [niobokupletskite: $94.6^{\circ}$; kupletskite: $99.2^{\circ}$ (Christiansen et al. 1998)] as a result of this displacement. The net result of all these modifications is the significant decrease in distortion of the $D$ polyhedra [ $\Delta$ (niobokupletskite): 1.526 versus $\Delta$ (kupletskite): 17.840$]$.

\section{DISCUSSION}

The proposed coupled substitution between kupletskite and niobokupletskite appears to be extensive. In samples of Mn-dominant astrophyllite-group minerals

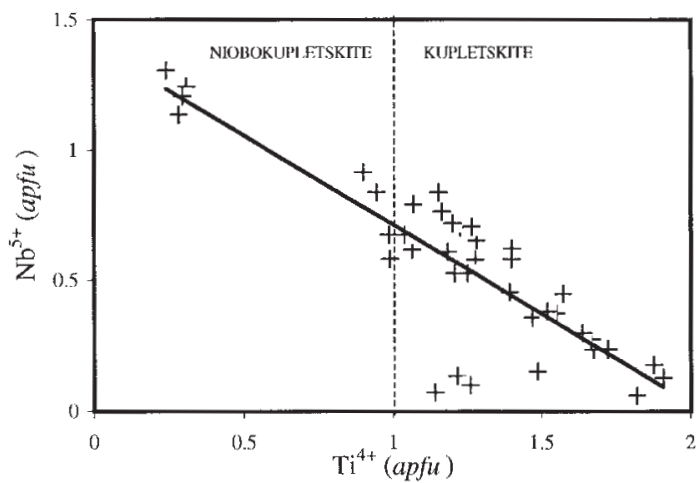

FIG. 7. Content of $\mathrm{Ti}^{4+}$ versus that of $\mathrm{Nb}^{5+}$ in the kupletskiteniobokupletskite solid-solution series. (Linear fit, $R^{2}$ : 0.742). from a variety of $\mathrm{SiO}_{2}$-undersaturated complexes, including Mont Saint-Hilaire, Lovozero (Kola Peninsula, Russia) and the Oslo rift (Langesundsfjord area, Norway), a strong negative correlation exists between levels of $\mathrm{Nb}$ and $\mathrm{Ti}$ (Fig. 7) and between $\mathrm{Nb}$ and $\mathrm{F}$ (Fig. 8). The average $\mathrm{Nb}$ content of Mn-dominant astrophyllitegroup minerals from these localities ranges from 0.06 to 1.33 apfu (67\% Nb-for-Ti substitution) with an average $\mathrm{F}$ content of 0.11 to 0.95 apfu (89\% O-for-F substitution; P. Piilonen, unpubl. data).

The incorporation of $\mathrm{Zn}$ into the niobokupletskite structure, and into astrophyllite-group minerals in general, may offer an indication of the sulfur fugacity, $f\left(\mathrm{~S}_{2}\right)$, at the time of crystallization. Electron-microprobe analyses indicate a bimodal distribution of $\mathrm{Zn}$ in niobokupletskite (Table 1); type-I niobokupletskite contains $0.73 a p f u \mathrm{Zn}$, whereas type-II and type-III niobokupletskite do not contain essential Zn (Table 2). Type-III niobokupletskite is associated with wurtzite and genthelvite $\left[\mathrm{Zn}_{4} \mathrm{Be}_{3}\left(\mathrm{SiO}_{4}\right)_{3} \mathrm{~S}\right]$, two of only six $\mathrm{Zn}$ bearing species to be described from Mont Saint-Hilaire (Horváth \& Gault 1990). The presence of a $(\mathrm{Zn}, \mathrm{S})$-bearing species in association with Zn-free niobokupletskite (type III) and of Zn-bearing niobokupletskite in the absence of associated $\mathrm{Zn}-\mathrm{S}$ species (type I), suggests that $\mathrm{Zn}$ readily enters into the astrophyllite-group mineral structure in conditions where the $f\left(\mathrm{~S}_{2}\right)$ is too low to allow for the crystallization of a separate $\mathrm{Zn}-\mathrm{S}$ species. The presence of wurtzite (the S-deficient hexagonal polymorph of $\mathrm{ZnS}$ ) rather than sphalerite is of interest in this respect. Hydrothermal synthesis studies of the univariant wurtzite-sphalerite boundary have shown wurtzite to be stable at low $f\left(\mathrm{~S}_{2}\right)\left(<10^{-10} \mathrm{~atm}\right)$, and over a wide range of temperatures, as low as $100^{\circ} \mathrm{C}$ in diagenetic environments, thus contradicting the previously established inversion temperature of $1020^{\circ} \mathrm{C}$ (Scott \& Barnes 1972). At higher values of $f\left(\mathrm{~S}_{2}\right)\left(>10^{-10} \mathrm{~atm}\right)$ and low temperatures $\left(<465^{\circ} \mathrm{C}\right)$, sphalerite is the dominant $\mathrm{ZnS}$ polymorph. Sphalerite is ubiquitous at Mont

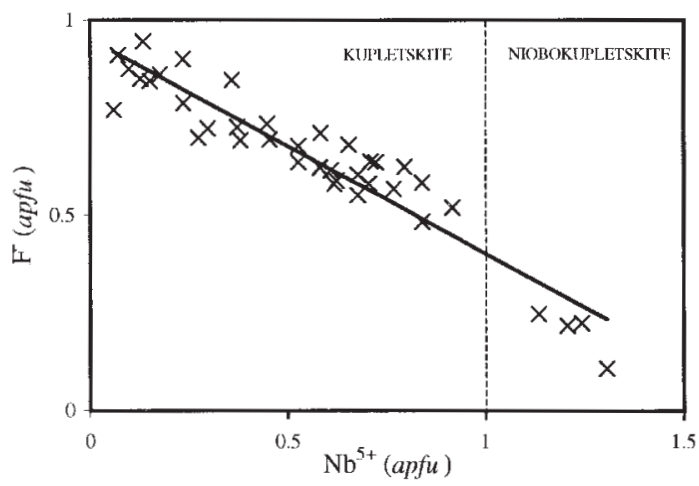

FIG. 8. Content of $\mathrm{Nb}^{5+}$ versus that of $\mathrm{F}^{-}$in the kupletskiteniobokupletskite solid-solution series. (Linear fit, $R^{2}$ : 0.893). 
Saint-Hilaire as a late-stage phase in all the microenvironments, most commonly associated with other S-bearing species (i.e., pyrite, pyrrhotite; Horváth \& Gault 1990). The absence of sphalerite in samples containing niobokupletskite suggests that the $f\left(\mathrm{~S}_{2}\right)$ was too low to permit the formation of sphalerite, resulting in the formation of either S-deficient wurtzite or of zincian niobokupletskite.

The controls on the distribution of high-fieldstrength elements in the magma, and subsequently into alkali titano-, zircono- and niobosilicates such as those of the astrophyllite group, may contribute to an understanding of the parageneses of these minerals. For example, in peralkaline systems, zirconium shows a high solubility and a highly incompatible nature in the melt until the final stages of crystallization (Bowden 1966, Larsen 1973, Watson 1979, Dunn \& McCallum 1982, Linthout 1984, Rubin et al. 1993). The high solubility of $\mathrm{Zr}$ in alkali-rich magmas can be attributed to the fact that $\mathrm{Zr}$ acts as a network modifier (Linthout 1984). An increase in the alkali content in the melt $(\mathrm{Na}+\mathrm{K})$ results in an increase in the proportion of non-bridging oxygen atoms to which $\mathrm{Zr}$ will preferentially bond, inhibition of ${ }^{[7]} \mathrm{Zr}$ and ${ }^{[8]} \mathrm{Zr}$, and promotion of ${ }^{[6]} \mathrm{Zr}$, leading to the incorporation of minor $\mathrm{Zr}$ into silicates such as pyroxenes and amphiboles, which have [6]-coordinated sites similar to those occupied by $\mathrm{Zr}$ in the melt polymers (e.g., aegirine; Piilonen et al. 1998). Decreasing temperature, increased $\mathrm{Ca}$, and increased $f\left(\mathrm{O}_{2}\right)$ result in melt polymerization, decreased solubility of $\mathrm{Zr}$, increased bonding between $\mathrm{ZrO}_{6}$ and $\mathrm{SiO}_{4}$ groups, and the formation of charge-balanced ${ }^{[6]} \mathrm{Zr}-\mathrm{O}-(\mathrm{Si}, \mathrm{Na})$ bonds within the melt (Linthout 1984, Farges et al. 1994). In all samples of niobokupletskite, the $\mathrm{Zr}$ :Ti ratio is greater than one $(\mathrm{Zr} / \mathrm{Ti}$ : 1.38 to 1.91$)$, suggesting that conditions were such to allow for decreased $\mathrm{Zr}$ solubility and preferential incorporation of $\mathrm{Zr}$ rather than $\mathrm{Ti}$ into the niobokupletskite structure. The high $\mathrm{Fe}^{3+} / \mathrm{Fe}_{\text {tot }}$ ratio obtained by Mössbauer spectroscopy and the coupled substitution of $\mathrm{Nb}^{5+}$ and $\mathrm{O}^{2-}$ in the niobokupletskite series both suggest a highly oxidizing environment of formation of niobokupletskite. As such, it appears that $\mathrm{Zr}$ and $\mathrm{Nb}$ may behave similarly in a peralkaline melt, unlike $\mathrm{Zr}$ and Ti which behave independently and either partition into discrete $\mathrm{Zr}$ or $\mathrm{Ti}$ phases or else are strongly ordered into separate sites in a given mineral structure (Pyatenko \& Voronkov 1978). The late-stage development of $(\mathrm{Ca}+\mathrm{Si}+\mathrm{Nb})$-bearing pyrochlore-group minerals in fractures within both niobokupletskite and primary kupletskite, and the presence of abundant late-stage catapleiite in association with niobokupletskite, suggest an increase in the $(\mathrm{Ca}+\mathrm{Zr}+\mathrm{Nb})$ concentration during the final stages of crystallization from a residual melt, followed by the formation of niobo- and zirconosilicates. Zirconium-rich niobokupletskite may represent an intermediate phase between early $\mathrm{Zr}$-rich pyroxene and late-stage $\mathrm{Zr}-\mathrm{Nb}$ minerals (e.g., catapleiite, franconite). The source of $\mathrm{Nb}$ in niobokupletskite may be attributed to the local dissolution of primary Nb-rich kupletskite (on which fibers of the former have nucleated) or $\mathrm{Nb}$ bearing minerals such as those of eudialyte group. More information regarding the distribution of $\mathrm{Nb}$ at Mont Saint-Hilaire is required before these hypotheses can be tested.

\section{ACKNOWLEDGEMENTS}

The authors thank Dr. G. Yap and the Department of Chemistry, University of Ottawa, for access to the CCD diffractometer, Mr. A.C. Roberts for obtaining the powder XRD pattern, Mrs. E. Moffatt of the Canadian Conservation Institute for performing the IR analyses, Dr. D.G. Rancourt of the Department of Physics, University of Ottawa, for use of the Mössbauer spectrometer, and Dr. P. Tarassoff and Mr. Q. Wight for providing samples. Special thanks also to Dr. Tarassoff for providing extensive information regarding the collection of the "witch"s broom astrophyllite" and associated minerals discovered on July $12^{\text {th }}, 1970$ (Wight \& Chao 1986). Thanks also to Drs. J.D. Grice and T.S. Ercit for their help and insight. The comments and suggestions provided by two referees, Drs. J. Stolz and S. Merlino, along with additional comments by R.F. Martin, are greatly appreciated and have increased the quality of this manuscript. Financial support was provided by the Natural Sciences and Engineering Research Council of Canada in the form of a scholarship to PCP and grants to AEL and AMM, and by the University of Ottawa and Laurentian University.

\section{REFERENCES}

Adams, F.D. (1903): The Monteregian Hills - a Canadian petrological province. J. Geol. 11, 239- 282.

Balí́-Žunić, T. \& Vicković, K. (1996): IVTON. A program for the calculation of geometrical aspects of crystal structures and some crystal chemical applications. J. Appl. Crystallogr. 29, 305-306.

Bowden, P. (1966): Zirconium in Younger Granites of northern Nigeria. Geochim. Cosmochim. Acta 30, 985-993.

BRESE, N.E. \& O'KeEFFE, M. (1991): Bond-valence parameters for solids. Acta Crystallogr. B47, 192-197.

Brown, I.D. \& SHANnON, R.D. (1973): Empirical bond strength - bond length curves for oxides. Acta Crystallogr. A29, 266-282.

Christiansen, C.C., Johnsen, O. \& StÅHL, K. (1998): Crystal structure of kupletskite from the Kangerdlugssuaq intrusion, East Greenland. Neues Jahrb. Mineral., Monatsh., 253-264.

Dunn, T. \& McCallum, I.S. (1982): The partitioning of $\mathrm{Zr}$ and $\mathrm{Nb}$ between diopside and melts in the system diopside - albite - anorthite. Geochim. Cosmochim. Acta 46, 623-629. 
Efimov, A.F., Dusmatov, V.D., GanZeEv, A.A. \& Kataeva, Z.T. (1971): Cesium-kupletskite, a new mineral. Dokl. Acad. Sci. USSR, Earth Sci. Sect. 197, 140-143.

Ercit, T.S., Cooper, M.A. \& Hawthorne, F.C. (1998): The crystal structure of vuonnemite, $\mathrm{Na}_{11} \mathrm{Ti}^{4+} \mathrm{Nb}_{2}\left(\mathrm{Si}_{2} \mathrm{O}_{7}\right)_{2}$ $\left(\mathrm{PO}_{4}\right)_{2} \mathrm{O}_{3}(\mathrm{~F}, \mathrm{OH})$, a phosphate-bearing sorosilicate of the lomonosovite group. Can. Mineral. 36, 1311-1320.

Farges, F., Brown, G.E., Jr. \& Velde, D. (1994): Structural environment of $\mathrm{Zr}$ in two inosilicates from Cameroon: mineralogical and geochemical implications. Am. Mineral. 79, 838-847.

FARMER, V.C. (1974): Infrared Spectra of Minerals. Mineral. Soc., Monogr. 4.

Ferraris, G., Ivaldi, G., Khomyakov, A.P., Soboleva, S.V., Belluso, E. \& Pavese, A. (1996): Nafertisite, a layer titanosilicate member of a polysomatic series including mica. Eur. J. Mineral. 8, 241-249.

HoRváth, L \& Gault, R.A. (1990): The mineralogy of Mont Saint-Hilaire, Québec. Mineral. Rec. 21, 284-359.

Hubei Geologic College, X-Ray Laboratory (1974): The crystal chemistry of astrophyllite-group minerals. Sci. Geol. Sinica 1, 18-33 (in Chinese).

KAPUSTIN, Yu.L. (1973): Zircophyllite, the zirconium analogue of astrophyllite. Int. Geol. Rev. 15, 621-625.

LAGAReC, K. \& RAnCourt, D.G. (1998): RECOIL. Mössbauer spectral analysis software. Department of Physics, University of Ottawa, Ottawa, Canada.

LARSEN, L. (1973): Measurement of solubility of zircon $\left(\mathrm{ZrSiO}_{4}\right)$ in synthetic granitic melts. Trans. Am. Geophys. Union (Eos) 54, 479 (abstr.).

LIEBAU, F. (1985): Structural Chemistry of Silicates: Structure, Bonding and Classification. Springer-Verlag, Berlin, Germany.

LinTHout, K. (1984): Alkali-zirconosilicates in peralkaline rocks. Contrib. Mineral. Petrol. 86, 155-158.

MANDARINO, J.A. (1981): The Gladstone-Dale relationship. IV. The compatibility concept and its application. Can. Mineral. 19, 441-450.

Mellini, M. \& Merlino, S. (1979): Refinement of the crystal structure of wöhlerite. Tschermaks Mineral. Petrogr. Mitt. 26, 109-123.

Moore, P.B. \& ARAKI, T. (1977): Samuelsonite: its crystal structure and relation to apatite and octacalcium phosphate. Am. Mineral. 62, 229-245.

Nickel, E.H., Rowland, J.F. \& Charette, D.J. (1964): Niobophyllite - the niobium analogue of astrophyllite; a new mineral from Seal Lake, Labrador. Can. Mineral. 8, 40-52.
Peng, C.C. \& MA, C.S. (1963): Crystal structure of astrophyllite and a new type of band silicate radical. Sci. Sinica 12, 272-276.

Pillonen, P.C., McDonald, A.M. \& Lalonde, A.E. (1998): The crystal chemistry of aegirine from Mont Saint-Hilaire, Quebec. Can. Mineral. 36, 779-791.

Pyatenko, Y.A. \& Voronkov, A.A. (1978): Comparative crystal-chemical functions of titanium and zirconium in mineral structures. Int. Geol. Rev. 20, 1050-1058.

Rancourt, D.G., McDonald, A.M., Lalonde, A.E. \& Ping, J.Y. (1993): Mössbauer absorber thickness for accurate site populations in Fe-bearing minerals. Am. Mineral. 78, 1-7.

\& PING, J.Y. (1991): Voigt-based methods for arbitrary-shape static hyperfine parameter distributions in Mössbauer spectroscopy. Nucl. Instrum. Methods Phys. Res. B58, 85-97.

Rastsvetaeva, R.K. \& Dorfman, M.D. (1995): Crystal structure of Ba-lamprophyllite in the isomorphous lamprophyllite-barytolamprophyllite series. Kristallografiya 40, 1026-1029 (in Russ.).

Rubin, J.N., Henry, C.D., \& Price, J.G. (1993): The mobility of zirconium and other "immobile" elements during hydrothermal alteration. Chem. Geol. 110, 29-47.

ScotT, S.D. \& BARnES, H.L. (1972): Sphalerite-wurtzite equilibria and stoichiometry. Geochim. Cosmochim. Acta 36, 1275-1295.

Semenov, E.I. (1956): Kupletskite - a new mineral of the astrophyllite group. Dokl. Akad. Nauk SSSR 108, 933-936 (in Russ.).

ShanNON, R.D. (1976): Revised effective ionic radii and systematic studies of interatomic distances in halides and chalcogenides. Acta Crystallogr. A32, 751-767.

SHELDRICK, G.M. (1993): SHELXL-93. Program for the Refinement of Crystal Structures. University of Göttingen, Göttingen, Germany.

Shi, Nicheng, Ma, Zhesheng, Li, Guowu, Yamnova, N.A. \& Pushcharovsky, D.Yu. (1998): Structure refinement of monoclinic astrophyllite. Acta Crystallogr. B54, 109-114.

TAYLOR, R. (1999): The Crystal Chemistry of Amphiboles from Mont Saint-Hilaire, Québec. B.Sc. thesis, Laurentian University, Sudbury, Ontario.

Watson, B.E. (1979): Zircon saturation in felsic liquids: experimental results and applications to trace element geochemistry. Contrib. Mineral. Petrol. 70, 407-419.

Wight, Q. \& Chao, G.Y. (1986): Mont Saint-Hilaire revisited. Rocks and Minerals 61, 182-197.

Woodrow, P.J. (1967): The crystal structure of astrophyllite. Acta Crystallogr. 22, 673-678.

Received November 19, 1999, revised manuscript accepted March 11, 2000. 
